This is the author's version of a work that was accepted for publication in International Journal of Educational Development. Changes resulting from the publishing process, such as peer review, editing, corrections, structural formatting, and other quality control mechanisms may not be reflected in this document. Changes may have been made to this work since it was submitted for publication. A definitive version was subsequently published in International Journal of Educational Development Vol. 38, Sep 2014. DOI: 10.1016/j.ijedudev.2014.06.007. The article can be accessed online at http://www.sciencedirect.com/science/article/pii/S0738059314000546

Published as:

Dendir, Seife (2014) 'Children's cognitive ability, schooling and work: Evidence from Ethiopia', International Journal of Educational Development 38: 22-36.

The article is reproduced in accordance with the self-archiving policies of Elsevier. 


\title{
Children's Cognitive Ability, Schooling and Work: Evidence from Ethiopia
}

\author{
Seife Dendir \\ Radford University
}

(June 2014)

\begin{abstract}
I investigate the relationship between children's cognitive ability and parental investment using a rich dataset on a cohort of children from Ethiopia. The data come from Young Lives, a longterm international study of childhood poverty in four countries. Ability is measured by scores on a cognitive test. A child's enrollment in school, participation in work and work hours are employed as measures of parental investment in human capital. The results provide strong evidence of reinforcing parental investment - higher ability children are more likely to be enrolled in school and less likely to work and, conditional on participation, also work fewer hours. These results are mostly robust to addressing potential feedback effects between schooling and test scores and household heterogeneities. On the policy front, the results suggest that the seeds of adulthood inequality in human capital and earnings capability may be sown quite early in childhood, and thereby underscore the importance of interventions that, among others, attempt to improve prenatal and early life health and nutrition, which are often cited as the sources of deficiencies in children's cognitive ability.
\end{abstract}

Key words: cognitive ability, endowment, human capital, schooling, child work, Ethiopia

\section{Introduction}


The pattern of allocation of resources by parents among offspring with varying endowments can be compensating or reinforcing. Compensating allocations provide more resources to the less endowed, to enable equitable opportunities and quality of life later in adulthood. Early models of household utility maximization with intergenerational provision of resources assumed that parents inherently possess such a preference for equity among their children, and hence for compensating allocations (Becker and Tomes, 1976). However, this assumption was challenged soon after, on theoretical grounds as well as with evidence that market signals, such as differential earning opportunities in adulthood, can shape and dominate household behavior, possibly leading to reinforcing allocations (Behrman et al., 1982; Rosenzweig and Schultz, 1982). Very likely, idiosyncratic preferences combine with market mechanisms to determine the final nature of investments, the dynamics of which are highly dependent on relevant household characteristics, society's general level of development, market imperfections, and the degree of social and economic inequality. Such nonlinearities render the nature of intra-household allocation of resources largely empirical and contextual (Behrman, 1997).

Human capital investment often constitutes a core component of resources allocated to children by parents (the other takes the form of 'transfers'). Given preferences, testable implications consistent with compensating, reinforcing or neutral investments in human capital are derived from consensus models of the family (Behrman et al., 1982; Behrman, 1997 provides an extended review). Empirical tests, in turn, have mostly investigated differences in investment by a child's sex. This is mainly due to the fact that sex is the most directly observable genetic endowment. ${ }^{1}$ Variations in children's health endowment and whether parents invest to compensate or reinforce such inequalities have also been emphasized (see Pitt et al., 1990 for a seminal contribution).

A child's cognitive or educational ability, despite the presumed central role it plays in the efficiency (returns and costs) of human capital investment broadly, and educational investments specifically, has been the subject of fewer studies. This is largely because [innate] cognitive ability is unobservable to the researcher. Although they are available, IQ or ability tests are usually difficult to administer alongside large-scale household surveys that also collect the requisite information on a wide array of control variables. In spite of this difficulty from the point of view of the researcher, it can be argued that parents can adequately assess their children's ability, in relative if not absolute terms, and will likely condition their investment allocations on such differences in perceived ability.

In theory at least, the prevalent pattern of educational investment allocation is expected to be of the reinforcing type. To the extent that marginal product of investment in human capital increases in child endowment, an "economic" allocation should favor more endowed children. There are factors that could attenuate and may even alter this, however, including inequalityaverse parental preferences. Specific parametric assumptions about the human capital production and parental welfare functions are also crucial, as are total resources available for parents for allocation (Behrman, 1997).

\footnotetext{
${ }^{1}$ Also, gender exhibits interesting interactions with parental preferences, production technology and culture which, in combination, often translate into differences in general labor market opportunities, giving it a special role in studies that examine the endowment - investment relationship (Rosenzweig and Schultz, 1982; Behrman and Deolalikar, 1995).
} 
In this study I examine the nature of the association between children's educational endowment and parental investment in schooling using a unique longitudinal survey from Ethiopia. The contributions to the literature derive from the following. First, it uses a direct measure of children's perceived endowment. In two rounds of the survey, the full sample of children completed a widely-known standardized test of cognitive ability. Controlling for a rich array of child and household characteristics, the study therefore tests whether poor Ethiopian households condition educational investment decisions on their assessment of a child's ability and, if so, whether these decisions follow reinforcement or compensation. Only a handful of recent studies have used direct measures of ability in this context. Second, the educational investment decision is examined from two angles - child schooling and work. This is relevant because studies have shown that these two are not necessarily substitutes and drawing inferences about one (e.g. schooling status) based on the other (e.g. child work) can sometimes be fallacious. ${ }^{2}$ More importantly, by examining child work as a separate parental decision variable, the study also contributes to the now-extensive child labor literature that has almost entirely been unable to evaluate or isolate the endowment effect on child work in poor developing economies. In doing so, the effect on both the extensive and intensive margins of child labor is analyzed.

Bacolod and Ranjan (2008) is the study closest to this one in adopting a direct measure of educational endowment to examine the impact on child schooling as well as work. Using data from the Cebu metropolitan area in the Philippines, they report that children with higher scores on an IQ test are more likely to be in school even in poor (low wealth) households. Conversely, households of even moderate wealth may be opting to let low-ability children stay idle rather than sending them to school or work. The study, however, does not consider the amount or intensity of child work. Two more studies, Ayalew (2005) and Akersh et al. (2012a), employ data from a village in Ethiopia and a province in Burkina Faso, respectively, to measure children's ability using test scores and examine the association with child schooling. Both report higher rates of school enrollment for higher ability children. Neither study considered child work. ${ }^{3}$

Third, the data employed have attributes that are especially pertinent to a study of this type: (a) the cohort children are surveyed at two important junctures - ages twelve and fifteen when parents' say is still arguably the most important factor determining a child's status (e.g. in schooling and work), hence the latter's use to proxy parental human capital investment decisions; (b) the sample has extremely low attrition, which minimizes selection bias often associated with cohort data; (c) unlike most of the above-cited studies that were confined to a particular area/region, the sample in this study comes from about 20 sites in five major regions of Ethiopia, providing a balanced representation of the country's geographical, cultural and regional diversity, and enabling potentially broader inferences from the results; and (d) the surveys took

\footnotetext{
${ }^{2}$ Among other reasons, this could be due to the potential confounding effects of leisure (Ravallion and Wodon, 2000) and idleness (Biggeri et al., 2003), or possible complementarity between schooling and work (Admassie, 2003). Kim (2009) argues the suggested complementarity between schooling and work that is highlighted in some policy circles is often not grounded in evidence.

${ }^{3}$ To the best of my knowledge, Ayalew (2005) is the first study to adopt a direct measure of endowment (i.e. score on an ability test) in the specific literature. Interestingly, he also reports that although households seem to reinforce educational endowment, investment in health is compensating - less endowed children receive more health-related resources.
} 
place during a period in which Ethiopia recorded arguably the fastest growth in its economy as well as the largest expansion in schooling opportunities for children, especially at the primary level. The repeated cross-sectional analysis therefore is able to capture the impact, if any, the changing socio-economic conditions have had on the endowment-child schooling/work relationship.

Finally, it should be noted that estimation of the endowment effect using cognitive test score suffers from potential bias mainly because whether such a score measures pure ability is debatable. For instance, it is possible that test score at least partially reflects current and past schooling inputs and achievement, inducing reverse causation. More generally, unobserved household characteristics can also cause bias in cross-sectional estimations. The paper attempts to address these problems by using, respectively, a 'residual method' that utilizes the longitudinal nature of the data and estimation of a within-household model on sibling pairs.

The paper is organized as follows. The next section gives background of the study context by highlighting relevant statistics and determinants of child schooling and work in Ethiopia. Section 3 describes the data, variables of interest and some bivariate associations. Section 4 provides the empirical framework, followed by baseline results and sensitivity analyses in section 5. Section 6 discusses the results in the context of existing findings. The last section concludes and offers some policy remarks. The results generally point to a pattern of reinforcing investment by Ethiopian households in children's education: (a) Higher ability, as measured by score on an ability test, is positively correlated with a child's enrollment in school; (b) The likelihood of participating in market work is negatively associated with perceived ability; (c) Conditional on participation, higher ability children work fewer hours; and (d) Although these associations are between concurrent test score and child status at each age, they are also present after accounting for potential sources of bias. For example, they also hold firm when ability is measured as a residual to account for potential reciprocal effect from schooling, and when an alternate specification is used to account for unobserved household characteristics.

\section{Study Context}

Historically, Ethiopia had a poor record in various measures of children's schooling. At the turn of the Millennium, gross primary enrollment was about $62 \%$ and entry rate to primary school at the normal age (7 years) was $20 \%$, both of which were significantly worse than the corresponding averages for Sub-Saharan Africa (SSA) (World Bank, 2005). Reform efforts that began in 1993 had gathered pace in the last decade, however, allowing the country to register impressive results on certain fronts. A central objective of the government's educational reform program was increasing access to schooling, particularly in rural areas and at the primary level. That objective is largely being achieved. As of 2011, for example, net primary enrollment reached $86 \%$, compared to a SSA average of 75\% (World Bank, 2013).

Other dimensions of schooling are lagging, however. Completion rates are low. In 2011, primary completion rate was 58\%, relative to a SSA average of 70\% (World Bank, 2013). The push to expand access may also have significantly compromised quality. Resources per student, such as teacher to student and textbook to student ratios, are under considerable downward pressure 
due to financing constraints. Disparities in attainment by sex and location persist (Woldehanna et al., 2008b; Woldehanna, 2011a; Dercon and Singh, 2012; Rolleston, 2014; Frost and Little, 2014).

On the demand side, parental education, household income and wealth are shown to be important determinants of children's school enrollment and progress. In rural areas, for example, Mani et al. (2013) report that having a mother (father) with non-zero schooling increases the chances of a child's enrollment by 3 to 7 (7 to 10) percentage points. Income elasticity of primary enrollment is estimated to be 0.3 to 0.9 , and the income effect is even stronger on grade attainment and for girls. Sibling composition factors are also important. Generally, having more siblings and being a later-born child raise the chances of school enrollment (Woldehanna et al., 2008b). Although the evidence is mixed, distance to school and household shocks appear to have a negative impact on enrollment (Himaz, 2013; Woldehanna et al., 2008b).

By many accounts, child labor is also widespread in Ethiopia. Analysis of the first national labor force survey (NLFS 1999) indicated that average participation rates for 7-14 year-old boys (girls) in market work were 52\% (42\%) in rural areas and 14\% (8\%) in urban areas. For household work, the corresponding rates were $22 \%(41 \%)$ and $36 \%(52 \%)$ in rural and urban areas, respectively (Alvi and Dendir, 2011). A national child labor force survey later found that $62.4 \%$ of 10-14 year-olds were economically active (CSA, 2003). These ratios place the country high in a ranking by the incidence of child labor, even amongst SSA countries.

Furthermore, studies document that, generally, children's work burden negatively impacts enrollment and progress in school. Notwithstanding gender-based differences in participation by type of work, on average children from less educated and credit-constrained households are more likely to participate in work full-time or to combine work with school (Woldehanna et al., 2008a; Alvi and Dendir, 2011; Orkin 2012). Wealth and assets have a complex effect, however. Woldehanna et al. (2008a) estimate that below a certain threshold, rising wealth is associated with a higher probability that a child will combine schooling with work (relative to schooling only), whereas a household's land holdings did not have a significant effect on children's time use.

Some forms of social capital, for example household group membership, lessen the chances that a child will only involve in labor activities. Others, such as localized cultural norms may have a facilitative effect on child work, however, by sanctioning the view that children's contributions to household labor and resources are not only beneficial but also inevitable (Orkin, 2010). Finally, a child's age and birth order also determine the likelihood of involving in work, whereby older and earlier-born children are in a relatively disadvantaged position relative to their younger, later-born siblings (Alvi and Dendir, 2011).

At the policy level, some have argued that the country's core development strategy known as Agricultural Development Led Industrialization (ADLI), which aims to raise rural labor force participation, incomes and agricultural credit, especially for women - perhaps had unintended negative consequences for children's status. Woldehanna et al. (2008a) argue, for instance, that promotion of labor-intensive agricultural production may have led to higher demand for child labor on rural farms, consequently harming schooling. In another evidence, Orkin (2010) notes that the government's Productive Safety Net Program (PSNP), introduced in 2005 to combat food insecurity by offering families daily wages for unskilled work, has increased child labor supply. Although the PSNP does not formally avail the services of children, it is not 
uncommon for children to substitute for, or work alongside, their parents or other registered household members. Finally, the rise in women's labor supply without concurrent improvements in social and physical infrastructure for child care may have shifted household work responsibilities to female children (Woldehanna et al., 2008a).

\section{Descriptive Analysis}

\subsection{Data}

Data for the study come from the Young Lives (YL) project, a 15-year longitudinal study of childhood poverty at the Department of International Development, University of Oxford. The project involves 12,000 children in four countries: Ethiopia, India (Andhra Pradesh), Peru and Vietnam. Starting in 2002, the project has followed two cohorts of children in each country: the 'Younger Cohort' of 2000 children aged around 1 in 2002 and the 'Older Cohort' of 1000 children aged around 8 in 2002. In addition to the first round, so far the project has collected two more rounds of data on these children, in 2006 (aged 5 and 12) and 2009 (aged 8 and 15). The project has the stated aims of understanding the causes and consequences of childhood poverty and thereby informing the development of policies that will reduce it. To fulfill these objectives, the YL study collects extensive information on wide-ranging economic, social and environmental phenomena at the child, household and community levels.

I use data from the Ethiopia part of the YL project. The YL sampling procedure adopted sentinel site surveillance, where the sites were purposefully selected to meet study objectives, such as its poverty-centered focus, to optimize study sustainability, and to capture geographical and cultural diversity of the country and urban-rural differences. This was followed by random sampling of households within each site. Accordingly, the sample provides a balanced representation of the Ethiopian geographical, cultural and regional diversity. ${ }^{4}$ Furthermore, even though the survey is not nationally representative and cannot be used for monitoring of welfare indicators over time (e.g. as in the Demographic and Health Survey (DHS) and Welfare Monitoring Survey (WMS)), it is noted that the YL sample is an appropriate and valuable medium for the modeling, analysis and understanding of the dynamics of child welfare in Ethiopia (OutesLeon and Sanchez, 2008).

For this particular study the latter two rounds of data on the 'Older Cohort' of children (henceforth also identified by age at the time of survey: Age 12 and Age 15) are used. I focus on the older cohort because their ages during the surveys span a critical period in children's school status and involvement in household and outside work activities. Children in Ethiopia are expected to start school at age 7 and progress through most of primary school by age 14 . The data at ages 12 and 15 therefore provide valuable snapshots of a child's schooling status and progress around the middle and supposed late years of primary education. Furthermore, these are also ages when parents will arguably assume that children are physically and mentally maturing to be able to commence and increasingly engage in household and/or outside work. In poor households where direct and indirect/opportunity costs of a child's schooling are viewed as

\footnotetext{
${ }^{4}$ The sites were located in five regions/administrative states of the country: Addis Ababa, Amhara, Oromia, Southern Nations, Nationalities and Peoples' Region (SNNP), and Tigray.
} 
considerable, the years covered by the two rounds of data represent a critical period of decisionmaking in terms of allocation of resources and children's time use, with significant implications for long-term human capital accumulation of children. ${ }^{5}$

To examine the linkage between children's endowment and household decisions with regard to schooling/work, I make extensive use of the detailed information available at the child and household levels in the two rounds. One of the strengths of the YL study is that the surveys so far have experienced very low levels of sample attrition. Out of the 1000 older cohort of children that participated in the first round and keeping only observations with non-missing values for all the basic child and household variables, I was able to track 971 children across the latter two rounds (an attrition rate of 3 percent). Higher level of attrition (e.g. due to migration) are often associated with systematic changes in a cohort sample and lead to bias in analysis, but the very low attrition rate in the YL surveys means this is highly unlikely. Summary statistics on the variables of interest are presented in Tables 1a-1c, respectively on basic child and household characteristics, measures of endowment/ability, and child schooling and work.

Table 1a describes the basic child and household characteristics of the final sample. As noted earlier, the average age of the sample children as of survey date was 12 and 15 years, respectively, in rounds 2 and 3. About half of the sample is composed of females. Parents' years of schooling are very low, with an average of about 2 and 3 years, respectively, for the mother and father. 13 percent of children live with a caregiver who is neither the biological mother nor father (Other caregiver) and about a quarter reside in a female-headed household (Female head). Typically, a child lives in a household with 6.4 members and is expected to have about 3 siblings. About 90 percent of children report that they consider themselves to be of similar or better health relative to other children of the same age. However, about 15 percent on average report that they had experienced serious illness since the last survey round. ${ }^{6}$ About a fifth of households of YL children also listed illness of a parent or another member as a significant event that adversely affected their economy. On average, 41 percent of the sample children come from urban areas.

For the purposes of this paper, a child's endowment is measured by her score on a test of cognitive ability or intelligence. The older cohort in the YL study completed two such tests in the three rounds of data collection: the Raven's Colored Progressive Matrices (CPM) in round 1 (age 8) and Peabody Picture Vocabulary Test (PPVT) in rounds 2 and 3 (ages 12 and 15). Unfortunately in the Ethiopian version, administration of the Raven's test in the first round ran into difficulties relating to explanation of tasks and time constraints and thus only about a quarter of the sample - all urban children - have test scores available in the dataset. This is the reason why the analysis in this paper makes use of only the latter two rounds of the Ethiopian YL data. Cueto et al. (2009) note that these problems, coupled with further difficulties encountered in the Peruvian pilot tests for round 2, prompted the abandonment of the CPM, though it may yet be brought back for future rounds. ${ }^{7}$

\footnotetext{
${ }^{5}$ As will be noted below, the first round (Age 8) data on the older cohort could not be used in this study because only about a quarter of the sample children had taken the test of cognitive ability.

${ }^{6}$ The relevant question in round 2 inquired about serious illness or injury, whereas in round 3 it was just about serious illness.

${ }^{7}$ An earlier version of this paper included analysis of round 1 data using the limited sample of children who took the CPM. Most of the results were qualitatively similar to those obtained from rounds 2 and 3.
} 
The PPVT, which was adopted for rounds 2 and 3, is a test widely applied to measure verbal ability/scholastic aptitude and general cognitive development since its inception in 1959. It is untimed, does not require reading on the part of the respondent, is relatively easy to administer, and can be completed in about 20-30 minutes. The test is documented to have strong positive correlation with other common measures of intelligence such as the Wechsler and McCarthy Scales (see Campbell, 1998; Campbell et al., 2001, among others), although the evidence on the extent to which it is entirely free from cultural bias is contested. The object of the exercise to the test-taker is to identify one picture, among a set of four pictures presented, that corresponds to a word read out by the examiner. The test has gone through many revisions over time and PPVT-III (Dunn and Dunn, 1997; Form A) was the version used in YL rounds 2 and 3. The PPVT contains 17 sets of 12 items each, arranged in order of difficulty, and the starting set for a respondent varies depending on his/her age. Progress through (up or down) sets is decided by performance during the test, eventually determining what are known as the Basal and Ceiling Item sets for each individual. Scores are then computed by subtracting the number of errors from the individual's Ceiling Item.

In light of the concern about potential culture bias, several steps were taken by the YL team to ensure the PPVT was adapted to the relevant study sample and local conditions (Cueto et al., 2009; Cueto and Leon, 2012). This comprised conducting a pilot test before each round that involved two steps. First, a diverse local panel of experts was convened to assess the test itemby-item for 'fairness' from multiple dimensions, including appropriateness to the local culture and nuances, and its neutrality with respect to gender, location (urban versus rural) and group (majority/minority). Based on its assessment, the panel chose what it considered to be non-biased items from the PPVT and adapted, replaced or discarded the rest to construct its own national version of the test. Moreover, the test was translated to all the main local languages that were spoken by the YL sample children. Second, the pilot instrument was administered to a sample of non-YL children that was selected to mirror the characteristics and environments of the YL sample. The collected pilot data was then analyzed by the core YL team as well as the local panel of experts, which led to further refinements of the test. These refinements were intended to ensure the test instrument captures wide variability in children's abilities, yields data with comparable underlying constructs across rounds, and facilitates administration during surveys. In combination, these steps underscore the fact that the YL research team was acutely cognizant of potential bias that could result from adopting a test, which was originally developed in the West, to measure cognitive ability of Ethiopian children. They also highlight the efforts that were made to minimize such bias.

Furthermore, after each round of the YL surveys, the psychometric properties of the data from the PPVT and other tests were thoroughly analyzed for reliability and validity (see Cueto et al., 2009 for round 2; Cueto and Leon, 2012 for round 3). In addition to various other diagnostics, the studies employed procedures in Classical Test Theory (CTT) and Item Response Theory (IRT) to assess reliability. For validity, they checked whether the PPVT data correlated with other background and demographic variables in a manner predicted by theory and previous studies. In both rounds, reliability indexes computed using CTT and IRT for the Ethiopian PPVT data comfortably exceeded the threshold/acceptable levels. Test scores also exhibited high correlations with several other variables, such as parental schooling and household wealth, as predicted. As 
part of the item-by-item diagnostic processes, Cueto et al (2009) and Cueto and Leon (2012) employed detailed criteria to exclude items with poor fit, low item-test correlation and acrossgroup bias, and generated corrected and Rasch PPVT scores. Both of these showed very high correlations (well over 90\%) with the raw PPVT scores. In sum, whereas normality and a potential ceiling effect (in Round 3) were issues of concern, the various analyses have shown that in both rounds the YL PPVT tests perform well in fulfilling their purpose, which is capturing the variation in ability among children in the study sample.

Cueto et al. (2009) also argue that converting raw scores to [international] standard PPVT scores is possible but not necessarily advised, since the standardization samples are deemed to be different from the YL sample. Moreover, the objective of this study is to examine how differences in perceived ability among a cross-section of same-age children in Ethiopia are related to schooling/work status and outcomes, not measuring their standing vis-à-vis an international norm, and thus the raw score is adopted as a measure of ability. Table $1 \mathrm{~b}$ shows summary statistics of the raw PPVT scores in the two rounds.

Turning to the dependent variables of interest, parental human capital investment is viewed from two angles: child schooling and work. Table 1c provides summary statistics on the relevant variables. Schooling is measured primarily by current enrollment, which equals one if the child was enrolled in school at the time of survey, zero otherwise. For comparison, I also define 'Ever enrolled', which shows if the child has ever attended formal school. 97 percent of children indicated that they had by age 12 and this figure rises to 99 percent by age 15.95 percent of children were in school at the time of survey at age 12, which falls to 90 percent at age 15 . A child's completed years of schooling as of survey date (Grade completed) measures schooling achievement and is constructed for use in a sensitivity analysis later in the paper. Conditional on ever enrolling in school, the mean for highest grade completed rises from 3.3 at age 12 to almost 6 by age 15 .

Table 1c provides summary statistics on child work as well. Child work is measured at the extensive and intensive margins - that is, both as participation in and amount of work. It should be noted that the YL survey questionnaires in rounds 2 and 3 contained a separate section on children's time use, which collected detailed information on the hours spent by the child on various activities on a typical day during the week prior to the survey. The activities included, among others, work for pay, on family farm or business, and on various chores. Based on the standard definition in the child labor literature, 'Work status' is defined as a dummy variable which equals one if the child reported non-zero hours on paid work (hired or self) or on family farm/business, zero otherwise. In the literature this is identified as market work and as such excludes household chores and related domestic tasks. According to the statistics, at age 12, 48 percent of the sample children were involved in market work which decreases to about 46 percent by age $15 .{ }^{8}$ Conditional on participation, the number of hours spent on market work on any given day in the week preceding the survey rises from 3.3 at age 12 to 3.8 at age 15 . Taking into account the likelihood of engaging in market work and the reported mean hours, one can conclude that

\footnotetext{
${ }^{8}$ Although not shown, the interplay between the different types of market work at the two 'ages' is interesting. For instance, the proportion of children who engage in paid work doubles from age 12 to age 15 (4 to 8 percent), but those who work on the family farm/business actually declines (from about 45 to 39 percent).
} 
the amount of work undertaken by Ethiopian children is far from trivial. This paper examines whether parents' decision on the allocation of schooling and labor is influenced by their perception of children's endowment/ability.

One would expect that children's ability is more likely to become a factor in the parental investment decision if households face significant budget or borrowing constraints. To check whether this is the case for Ethiopian households, I examine the reasons for non-enrollment among children who were not in school. In the YL surveys, non-enrolled children as well as their caregivers are asked to give the main reasons why they are not in school. Table $1 \mathrm{~d}$ provides the distribution of reasons by major categories. Two features of the distributions stand out. First, the two distributions - children's and caregivers' - are highly correlated in both rounds. The only exceptions to this are "financial problems" at Age 12, which is more likely to be cited as a reason for non-enrollment by children than parents, and "lack of interest or behavioral problems" at Age 15 , which is twice as likely to be cited by parents as a reason why a child is not in school. There is a notable margin between the two groups in the proportion who chose "Other" or did not specify a reason. ${ }^{9}$

Second, in both rounds, a significant proportion of children and caregivers provided reasons for non-enrollment that are indicative of budget- or borrowing-constrained households. Among children, "financial problems" or "to work for household or for pay" were cited as the primary reasons for non-enrollment $43 \%$ and 50\% of the times at Age 12 and Age 15, respectively. Among caregivers, the two reasons collectively accounted for 39\% and 49\% of the responses. These statistics suggest that among Ethiopian households the costs of schooling - direct and indirect - can indeed be prohibitive in the decision to send a child to school. Furthermore, reasons such as "to look after siblings", "to look after ill or elderly members" and "schooling not needed for job/trade" signify that households perceive the returns from children's schooling to be low, at least in the short to medium term. These reasons account for a further $5 \%$ to $16 \%$ of the responses in the two rounds. In sum, approximately three out of every five children are reported to be out of school due to reasons related to cost or perceived low benefits. This is typically a scenario where parental assessment of a child's ability may indeed play a role in the decision to invest scarce household resources in her education.

\subsection{Bivariate Associations}

The possible link between children's endowment and their schooling and work is first illustrated using simple bivariate analysis. Figures 1.1 and 1.2 present average school enrollment by test score quintile at ages 12 and 15. Clearly, one can observe a positive trend in the probability of a child ever/currently enrolling in school and her quintile test score. At age 12, for instance, the likelihood of a child in the lowest quintile to have ever been enrolled in school is about 88 percent, while all children in the top quintile are enrolled in school. With the almost monotonic relationship between current enrollment and test score, the graph at age 12 is probably most

\footnotetext{
${ }^{9}$ In the questionnaires, 'low ability' was not offered among the choices as to why a child was not enrolled in school.
} 
supportive of the hypothesis that a child's perceived endowment may indeed be a factor in the parents' decision to enroll her in school, assuming such a decision overwhelmingly, if not solely, rests with the parents. Similarly, by age 15, whereas children of all abilities except those in the bottom quintile had been enrolled in school at one time or another, the positive correlation between current enrollment and test score is palpable. A quarter of children of the lowest ability, for example, are out of school by that age, while the corresponding figure for those in the top two quintiles is less than 5 percent.

Figures 2.1-2.4 present the bivariate associations between child work and score on the PPVT at ages 12 and 15. At both ages, participation in market work declines, almost monotonically, by test score quintile. For instance, children in the bottom quintile of ability have, on average, a more than 60 percent chance of engaging in market work, while those in the top quintile are less than half as likely. Most of this decline can be attributed to the significant decrease in the likelihood of engaging in family farm/business work, although the drop in participation in paid work associated with most jumps in test score quintile is not insignificant either, albeit from a small base. When it comes to the amount of work, the general trend is also negative, as shown by the mean hours of work by test score at age 12 as well as $15 .{ }^{10}$ In sum, the bivariate correlations between children's cognitive test score and work are also strongly suggestive of a child's endowment being a consideration in the parental human capital investment decision.

\section{Empirical Framework}

The baseline multivariate framework used to test the relationship between children's endowment and parental human capital investment is given by:

$$
H_{i}=\beta_{0}+\beta_{1} E_{i}+\sum_{j=1}^{m} \delta_{j} Z_{i j}+\varepsilon_{i}
$$

where $\mathrm{H}_{\mathrm{i}}$ is a proxy for human capital investment on child $\mathrm{i}$ (school enrollment, work status or work hours), $E_{i}$ is educational endowment measured by test score, $Z_{i}$ contains various child and parental/household characteristics that potentially impact children's status, and $\varepsilon_{\mathrm{i}}$ is the regression error term. $\beta_{1}$ measures whether children's human capital status is statistically related to endowment, whereby the sign determines if the latter is being reinforced $\left(\beta_{1}>0\right.$ for schooling; $\beta_{1}<0$ for work) or compensated ( $\beta_{1}<0$, for schooling; $\beta_{1}>0$ for work).

Equation (1) is estimated separately at the two ages (12 and 15). As noted, score on the PPVT is used to measure children's endowment/ability. The empirical specification controls for four groups of child and household characteristics in estimating the endowment - investment relationship. The child's sex accounts for potential discriminatory human capital investment behavior along gender lines in poor households in Ethiopia. ${ }^{11}$ The parental/household controls include parents' schooling, whose effect through improving the quality and efficiency of parent-

\footnotetext{
${ }^{10}$ However, when partitioned by type of work there is a rather peculiar increase in hours spent on work for pay (between the third and fifth quintiles) and on family work (between the second and third quintiles) at age 15.

${ }^{11}$ As will be seen later, in extended specifications the child's sex is also interacted with test score to check if reinforcing or compensating behavior exhibits gender-based nonlinearities.
} 
child time and other complementary inputs, among other channels, has long been established as crucial for children's educational status and outcomes (Haveman and Wolfe, 1995). Whether or not a child lives with her parent as the main caregiver may be particularly pertinent in order to realize these benefits, however, therefore this is controlled for using a dummy variable.

To account for various effects related to household demographics, such as life-cycle position, earnings capabilities and maternal health and experience, I also include head's and caregiver's age, headship status and number of adults residing in the household. The relevant literature has also shown that increased household resources are associated with many desirable schooling outcomes and decreased child work (Filmer and Pritchett, 1999; Edmonds, 2008). For this, a composite index of household wealth and household nondurable expenditure are included as regressors. ${ }^{12}$

The third set of control variables account for sibling demographics - sibling size, birth order, number of sisters and infant siblings. Studies have documented that sibling demographics - primarily birth order and sex composition - have important implications to a child's schooling and work status. These are mainly due to cultural influences, changes in parents' experience, health and earnings over time, evolving patterns in between-sibling comparative advantage, and fertility choice (Edmonds, 2008). The majority of evidence from developing countries suggests that earlier-born children, particularly females, tend to do worse than their siblings in various human capital measures. Similarly, having more sister siblings is correlated with favorable outcomes (Patrinos and Psacharopoulos, 1997; Garg and Morduch, 1998).

It has been well noted in the literature that children's health is an important determinant of their school and other activities as well as their long term human capital accumulation (Strauss and Thomas, 1998). A child's performance on an ability test is also naturally associated with her health. To account for this, the fourth set of control variables includes measures of child health. To measure long-term health, variables indicating a child's own assessment of her health relative to other children of the same age are employed. Specifically, the regression includes dummy variables for children who reported having better health and those who reported having worse health, while the reference category is children who said they have the same health as their peers. ${ }^{13}$ To measure short- to medium-term changes in health, a variable indicating whether a child had experienced serious illness since the previous round is also included. Finally, as noted in Table $1 \mathrm{~d}$ as well as in the literature, health of parents and other household members can also impact children's status (see for example, Sun and Yao 2010). In the surveys, households were asked if illness of the YL child's parents or other household members was an important event that negatively affected the household's economy since the previous round. The regression thus accounts for such shocks using indicator variables for illness of parents and other household members.

\footnotetext{
${ }^{12}$ The reasoning behind including both is that one measures stock (wealth) and the other flow of resources (expenditure). Specifications that included each separately were estimated but not reported here, but there were no notable changes in estimates. The wealth index is a composite index of housing quality, durables and facilities and takes a value between 0 and 1 . A rescaled value $(\times 5)$ is included in the regressions.

${ }^{13}$ The YL surveys also asked caregivers to similarly compare their child's health relative to other children of the same age. The child and caregiver responses were highly correlated.
} 
Furthermore, site/community fixed effects are included in all specifications to control for various supply-side (e.g. school supply, costs and prices) and demand-side (e.g. differential female-male wage rate, youth employment opportunities) factors. A linear probability model (LPM) is adopted for the estimation of the school enrollment and work status regressions. For the child work hours regressions, which contain a large number of zero values for non-working children, a censored model such as tobit is appropriate. However, tobit estimates also suffer from inconsistency in a fixed effects framework due to the insufficient statistic problem (to condition the fixed effects out of the likelihood function). I report two sets of estimates for the work hours regressions: (1) tobit estimates that exclude the community fixed effects (as a baseline), and (2) estimates using Honoré's (1992) semiparametric least squares censored fixed effects regression model, which does not impose any parametric restrictions on the error term. In all regressions, robust standard errors are employed that account for clustering in sample design, which for the YL surveys is at the site/community level. ${ }^{14}$

\section{Results}

\subsection{Baseline Specification}

The results from the estimation of equation (1) are presented in Tables 2-4, respectively for children's school enrollment, participation in market work and work hours. As noted earlier, the estimation is done separately for each round/age. ${ }^{15}$ To allow a more informative interpretation of estimates, test score is entered in the regressions as a standardized/z-score (by subtracting the mean from the raw score and dividing by the standard deviation). In addition to a basic specification, an extended specification that allows for nonlinearities in the effect of test score through a squared term and interaction with a child's sex is reported.

Table 2 shows the results pertaining to school enrollment. Controlling for a large array of child, sibling and household characteristics, at both ages score on a cognitive test has a positive, statistically significant effect on a child's school enrollment. At age 12, a one standard deviation higher score on the PPVT test is associated with a 3 to 4 percentage point increase in the probability of a child's enrollment in school. At age 15, the effect is 6 to 7 percentage points. This is evidence in support of reinforcing investment in children's schooling - children of perceived higher ability are more likely to be enrolled in school, accounting for other factors that potentially affect children's school attendance. This positive endowment effect on school attendance does not seem to vary by a child's sex, although there is some evidence that it may be nonlinear (inverse U-shaped, at age 15).

\footnotetext{
${ }^{14}$ Nichols and Schaffer (2007) argue that, even in a fixed effects framework, clustering is desirable to allow for within-cluster correlation of unknown type.

${ }^{15}$ The reason why a child fixed effects model is not estimated is because the child's educational endowment, which once formed is presumably a mostly 'fixed characteristic', will be subsumed in the child fixed effect, rendering its effect separately unidentified. That 'endowment' is a mostly formed, fixed child characteristic by ages 12 and 15 seems to be borne out by the data - a Wilcoxon signed-rank test of the PPVT score at ages 12 and 15 yielded $p=0.89$, which means the null of same distribution cannot be rejected.
} 
If children of lower ability are less likely to be in school at any point in time, it may be that they are more likely to be involved in work. The work participation results in Table 3 indicate that this may indeed be the case. At ages 12 and 15 there is a statistically significant association between a child's cognitive skills, as measured by score on the PPVT, and her chances of engaging in market work. More precisely, a one standard deviation higher score on the PPVT is associated with a 3 to 5 percentage point decrease in the probability of involvement in market work at age 12. The impact at age 15 is even more substantial, closer to 6 to 9 percentage points, which on the high end amounts to a roughly 20 percent decrease in the mean probability of a child engaging in market work.

The work amount regressions in Table 4 provide further evidence. At Age 12 as well as 15 , time spent in market activity by a YL child on a typical day in the week preceding the survey is statistically smaller, after accounting for various child and household characteristics, the higher the child's cognitive ability. Based on the marginal effects from the tobit model, a one standard deviation increase in score on the PPVT is correlated with a 10 to 16 minute decrease in the amount of market work. ${ }^{16}$ In sum, the work regression results are also supportive of the reinforcement hypothesis - parents may be deciding to send to work children of smaller perceived endowment.

Many of the control variables in the regressions in Tables 2-4 exhibit the expected sign when statistically significant. More household resources are generally associated with higher school enrollment and less child work. For instance, a unit increase in the wealth index raises the chances of school enrollment at Age 15 by about 5 percentage points, while it lowers the chances of work at Age 12 by 6 percentage points. Living with a caregiver who is not a biological parent increases the likelihood of work for a child and decreases that of schooling. Children who live with "other caregiver" are 5 to 6 percentage points less likely to be in school and 8 percentage points more likely to be involved in market work.

Interestingly, larger sibling size is associated with higher probability of attending school, whereas being a later-born child decreases the likelihood. So does having more infants in the household, as it presumably increases time spent by children looking after their young siblings. Female children in the YL sample are 6 percentage points more likely than males to still be in school at age 15. Male children are also significantly more likely to be engaged in market work than females. As for health, children who report that they consider themselves to be of poorer health than other children of the same age are about 8 percentage points less likely to be enrolled in school relative to those who report having comparable health. At Age 15, having better health than peers is associated with a 4 percentage point increase in the probability of enrollment and a 7 percentage point decrease in that of work. Interestingly, children of worse health are also less likely to be working and, conditional on participation, spend less time in work, signifying the need for children to be in good health to undertake economic activity as well. While most of the

${ }^{16}$ The specifications that employ Honore"s semiparametric estimator yield qualitatively similar results, although the estimated coefficients are not easily interpretable due to unobserved fixed effects that have to be taken into account for final computation. Due to the non-straightforward nature of computing tobit marginal effects involving interaction terms, the extended specification is not estimated for the work hours regressions. 
household health variables are not statistically significant, there is indication that having an ill mother reduces the chances of market work for children.

\subsection{Addressing Potential Bias}

\subsubsection{Reciprocal effect from schooling to cognitive ability}

Two concerns arise in the estimation of the endowment effect $\left(\beta_{1}\right)$ in a specification such as (1). First, the extent to which a child's score on a cognitive test like the PPVT measures 'pure ability or endowment' is questionable. It could be that such a score at least partially reflects realized achievement in schooling - that is, schooling can create cognitive ability. The fact that the dependent variable employed for this study shows status (i.e. enrollment at the time of survey), and not achievement, possibly minimizes the bias. However, one would expect persistence in children's school enrollment and work status (current status is correlated with past), therefore bias arising from reverse causation remains a possibility. The reverse (and reciprocal) causality problem can be mitigated by the use of the 'residual method'. The discussion below outlines the logic and procedures behind this method.

To reiterate, the problem is that the YL children in the sample have on average completed 3.3 and 5.6 years of schooling at Age 12 and Age 15, respectively. Plausibly, this means a child's performance on the PPVT in each round is impacted by her realized schooling so far, as well as by her 'innate or endowed ability'. The challenge, therefore, is to try and separate the schooling component of performance on a cognitive test from the ability component. Taking advantage of the fact that there are two rounds of scores for each child, performance on the PPVT and the two components can be modeled in a pooled regression framework such as:

$$
P_{i t}=\theta_{0}+\theta_{1} G_{i t}+\sum_{j=1}^{k} \alpha_{j} X_{i j t}+e_{i}+u_{i t}
$$

where $P_{i t}$ is raw PPVT score of child $\mathrm{i}$ in round/age $\mathrm{t}(\mathrm{t}=12,15), G_{i t}$ is child's schooling achievement, $X_{i j t}$ captures observed child and household characteristics that possibly influence test score (e.g. child's age, parent's schooling), and the error term comprises a time-invariant child-specific component $\left(e_{i}\right)$ and a time-varying purely random component $\left(u_{i t}\right)$ with zero mean.

Obviously, the effect of schooling on test score is captured by the coefficient on $G_{i t}$, which will be proxied here by a child's completed grade at the time of survey. Assuming a child's innate or endowed cognitive ability is an unobserved, fixed characteristic it will form part of the regression error term and will be captured by $e_{i} \cdot{ }^{17}$ The following two steps are followed to obtain an estimate of $e_{i}$. First, equation (2) is estimated by Ordinary Least Squares (OLS) and the predicted residual is retrieved. Since the effect of schooling is explicitly accounted for through the covariate $G_{i t}$, by construction the retrieved residual is rid of the schooling effect. However, the predicted residual in each round still contains the fixed endowment component $\left(\widehat{e_{l}}\right)$ and the

\footnotetext{
${ }^{17}$ See footnote15 for corroborating evidence from test score distributions of child endowment likely being a 'fixed characteristic'.
} 
random error component $\left(\widehat{u_{l t}}\right)$. Thus, in the second step, for each child an arithmetic average of the residuals over the two rounds is computed. When doing so, under the assumption of a zeromean $\mathrm{u}_{\mathrm{it}}$, the random error washes out and the simple arithmetic average of the residuals will contain only the non-random $\widehat{e_{l}}$. $\widehat{e_{l}}$ can thus be said to measure "pure or innate" ability. ${ }^{18}$

Of course, the argument in this paper is that parents may condition schooling and work decisions on this "educational endowment" of a child, which they are able to observe over time. Therefore, once an estimate of $\widehat{e}_{l}$ is obtained through the residual method, it is inserted into the enrollment and work equations (Equation 1) in lieu of the PPVT score. The estimated coefficient on $\widehat{e_{l}}$ in a school/work equation will thus arguably capture a "pure" endowment effect (net of schooling). Since the standard errors in the second stage will be incorrect due to the use of the predicted residual term, standard errors obtained by bootstrapping are employed. The results of these schooling and work regressions using residual ability are presented in Tables 5-7. ${ }^{19}$

As can be seen from the results, higher residual ability raises the probability that a child is enrolled in school. It also lowers the chances of engaging in work for pay or on the family farm/business. Conditional on participation, higher ability is also associated with fewer hours of work. In all cases except work status at Age 15, the endowed ability effect is highly statistically significant. At age 15, there is further evidence of an inverse U-shaped effect on school enrollment and a U-shaped effect, albeit a weaker one, on work participation, both of which suggest the presence of a threshold beyond which the endowment effect may change course. In sum, to the extent that the residual method yields estimates reflecting a pure endowment effect, the results lend strong credence to the baseline results that Ethiopian households may be making school and work decisions in a manner that reinforces children's endowed educational ability.

\subsubsection{Unobserved household characteristics}

The second concern regarding the estimates in the baseline specification (1) is typical of crosssectional models - there is potential bias arising from unobserved child or household characteristics that are embedded in the error term. The inclusion of a large set of control variables was intended to minimize such sources of bias. However, confounding effects may remain. For example, a household's attitude and knowledge about the human capital accumulation process, an unobservable behavior, may affect not only current status of children but also earlier investments that aid the development of children's cognitive ability (e.g. early-life investment in

\footnotetext{
${ }^{18}$ This would also be equivalent to the child fixed effect in a fixed effects model. The results from the test score regressions are compiled in the appendix.

${ }^{19}$ It should be pointed out that the residual method cannot be considered a panacea to the causality problem as it relies on a few modeling assumptions. One of these assumptions, for instance, is the absence of systematic measurement error in test score in the two rounds. However, in the absence of an outside instrumental variable to proxy pure ability, it is arguably a second-best solution. Ayalew (2005) uses a similar method to measure health and educational endowment as a residual. Bacolod and Ranjan (2008) also use the residual from a test score regression to net out the schooling effect.
} 
health). Under certain assumptions, a household fixed effect model can be used to more firmly account for such unobserved household characteristics. ${ }^{20}$

For this, I utilize a unique feature of the YL surveys in round 3 (Age 15). Specifically in this round, one of the siblings of the YL child, in many cases the most proximate in order of birth, also took the PPVT and his/her score was recorded in the survey. By merging the sibling's performance on the PPVT with information on school attendance and time use in the week prior to the survey, I estimate a household fixed effect regression model of the form:

$$
H_{i f}=\beta_{0}+\beta_{1} E_{i}+\sum_{j=1}^{m} \delta_{j} Z_{i j}+F_{f}+\varepsilon_{i f}
$$

where $H_{\text {if }}$ is the human capital status of child i (YL or her sibling) in household $f, F_{f}$ is the household fixed effect, and the rest of the notations remain the same as in (1). The control variables in $Z_{i j}$ contain child-specific characteristics only since household covariates will now be subsumed in the household fixed effect. The child-level control variables include dummies for age (in years) and gender. The sibling PPVT scores are entered in the model after being age-wise standardized (by subtracting from a child's raw score the age-specific mean and then dividing by the age-specific standard deviation). After removing YL children with no sibling/s and observations with missing values for important variables, $673 \mathrm{YL}$ child-sibling pairs were identified. $^{21}$

The results are presented in Table 8. The estimate on test score can now be interpreted as the impact on a child's status of a between-sibling difference in ability. The results provide further support to the evidence in the baseline cross-sectional regressions of household investment that reinforces differences in children's perceived ability. A higher ability child is more likely to be in school, less likely to work and works fewer hours than her lower scoring sibling. Given the significance of the squared and interacted terms, again there is evidence of a non-linear on children's status that was apparent from the earlier results. For example, the results suggest that within a household, the ability effect may be smaller for female children.

\section{Discussion}

Using data from a sample that provides a balanced representation of Ethiopia's geographical, cultural and regional diversity, the analyses in this paper establish a strong relationship between children's cognitive ability and their school and work status. Specifically, the results show that children that score higher on an ability test are more likely to be enrolled in school and less likely to work. How do these results stack up against existing evidence? As noted earlier, the literature that examines the relationship between cognitive ability, measured directly using test scores, and investment in children's human capital is relatively scant. However, the results in this paper largely conform to the few existing findings.

\footnotetext{
${ }^{20}$ For instance, the assumptions require that these unobserved characteristics be persistent across time and have a uniform impact on children within a household.

${ }^{21}$ An observation is also removed if the sibling from whom information is acquired was aged below 7 or above 16, since the decision dynamic guiding their school and work status is likely structurally different from a 7-15 year-old YL child.
} 
For example, Ayalew (2005) had reported, using data from a village in Ethiopia, children who score higher on the Raven's Progressive Matrices test were more likely to be enrolled in school, which he presents as evidence that households allocate educational inputs in a reinforcing manner. In corroborating the interpretation, he notes that when parents were asked who would they choose if they had the resources to send only one child to school, the most common response was 'the child who was good at schoolwork'. Bacolod and Ranjan (2008) showed that among a sample of children in the Cebu metropolitan area, those who scored higher on an IQ test were more likely to be in school and less likely to be idle. Glick and Sahn (2010) examined test score data from $2^{\text {nd }}$ graders in Senegal and reported that higher ability then was strongly correlated with schooling progression seven years later, which they suggest may be due to parental investment driven by higher potential returns. Akresh et al (2012a) tested the ability/endowment hypothesis in a sibling rivalry framework, which stipulates that given market and resource constraints, children with fewer siblings of a favored characteristic will be better off. Their analysis using data from a province in Burkina Faso indicates reinforcing educational investment. For example, a child who has one sibling of higher ability - measured by score on the CPM - was $15 \%$ less likely to be currently enrolled in school. Evidence linking ability with children's work status is even more scarce, although Bacolod and Ranjan (2008) and, in a recent paper, Akresh et al. (2012b) had also documented that higher cognitive ability lowers the probability of child labor.

In a broader context, the results in this paper are also largely consistent with the wellnoted relationship in the academic literature between investment in children's health, nutrition and education in the early years and their status and outcomes in primary school and beyond (see for example, Glewwe et al., 2001; Grantham-McGregor et al., 2007). The main conduit for this link is the degree of cognitive development, for which the first few years of life are crucial. In the literature for developing countries, for instance, cognitive ability at preschool and around grade 1 is found to predict school enrollment and achievement later in life (Liddell and Rae, 2001; Stith et al., 2003). Using YL data, Sanchez (2009) links early nutrition and health to later cognitive outcomes among Peruvian children. Woldehanna (2011b), also using the Ethiopia part of YL data, shows early educational investment in the form of preschool attendance improves cognitive performance of children at ages 5 and 8. As such, the emphasis in this literature is on the direct role that reduced cognitive ability can play in hampering children's human capital accumulation down the years. Distinctly, the results in this paper suggest an indirect role since, in the face of income and other constraints, households may decide to send children of perceived lower ability to work instead of school. This indirect route can thus perpetuate and exacerbate the negative effects on long-term human capital accumulation of children. The evidence presented is also particularly pertinent to Ethiopia since the country registers a very high proportion of children under 5 years ( $60 \%$ or more, by some accounts) who face multiple risks to their cognitive and other development (see Grantham-McGregor et al., 2007).

\section{Conclusion and Policy Implications}

The overwhelming evidence that emerges from the analyses in this paper using data on a cohort of children from Ethiopia points towards a pattern of household investment in human capital that complements initial differences in children's educational endowment. The related literature 
suggests this is largely due to investment behavior that seeks higher future marginal returns. It can also be due to contemporaneous efficiencies in human capital production (e.g. higher ability children are less likely to fail grades or lag behind, etc.). The exact reason why this pattern of investment behavior dominates in Ethiopian households is difficult to say and is beyond the scope of the study.

However, the long-term consequence of reinforcing investment in human capital or in any other kind of endowment for that matter is clearer. It further accentuates initial differences in endowment or in the benefits that accrue to it. If schooling investments are complementing educational ability, they lead to inequalities in human capital accumulation and earning capabilities that are likely to persist much later into adulthood.

Policy interventions that aim to tackle the problem early on can take different forms. First, an intervention can be targeted at minimizing initial differences in acquired cognitive ability that arise from health-related investments. Studies have shown that deficiencies in prenatal and early life child/mother health and nutrition often lead to lower levels of cognitive ability in children. For example, using the India YL data, Helmers and Patnam (2011) report that child health at age one influences cognitive ability at age five, and that child health at age one is significantly impacted by parental care during pregnancy and early life.

Second, interventions aimed at ensuring enrollment of all school-age children in a household (e.g. through a conditional transfer) can effectively circumvent the problem of intrahousehold differences in investment in schooling. A similar strategy can help in reducing child labor as well since, as highlighted in the paper, an important reason why children are withdrawn from school is due to the high opportunity cost (e.g. in foregone earnings) for some households. To improve effectiveness, such interventions may be accompanied by stricter enforcement of child labor laws, albeit in a manner that recognizes local conditions and cultures. Using data from a YL site, Orkin (2010) for instance argues that a regulatory approach that bans harmful work and 'regulates' other work may be preferable to a broad, abolitionist approach to child labor. One reason for this is pragmatism - broad legislation of the sort that Ethiopia has, which bans all children younger than 14 from work, is difficult to enforce because it requires significant state capabilities. More importantly, banning all work, including non-harmful work, may not necessarily serve a child's best interests. This can be the case if, for example, earnings from such work are used to cover some schooling costs, if it aids in the accumulation of other forms of human capital (e.g. marketable work skills), or builds a child's sense of social worth and acceptance into society (see also Orkin, 2012).

Third, effective remedial programs in schools for lagging or low-ability children can to a certain degree compensate for household actions that widen differences in schooling achievement. Finally, basic intuition about parental concern for children's welfare suggests that reinforcing allocations are more probable when the household budget constraint is particularly binding, therefore various policies that are generally aimed at alleviating poverty and increasing household resources should also bear fruit in tackling the human capital inequality problem at one of its roots. 
Acknowledgement: The data used in this paper come from Young Lives, a 15-year study of the changing nature of childhood poverty in Ethiopia, India (Andhra Pradesh), Peru and Vietnam (www.younglives.org.uk). Young Lives is funded by UK aid from the Department for International Development (DFID) and co-funded from 2010 to 2014 by the Netherlands Ministry of Foreign Affairs. The views expressed here are those of the author. They are not necessarily those of Young Lives, the University of Oxford, DFID or other funders.

\section{References}

Admassie, A., 2003. Child labor and schooling in the context of a subsistence rural economy: Can they be compatible? International Journal of Educational Development 23(2), 167-185. 
Akresh, R., Bagby, E., De Walque, D., Kazianga, H., 2012a. Child ability and household human capital investment decisions in Burkina Faso. Economic Development and Cultural Change 61 (1), 157-186.

Akresh, R., Bagby, E., De Walque, D., Kazianga, H., 2012b. Child labor, schooling, and child ability. World Bank Policy Research No. 5965, World Bank.

Alvi, E., Dendir, S., 2011. Sibling differences in school attendance and child labor in Ethiopia. Oxford Development Studies 39 (3), 285-313.

Ayalew, T., 2005. Parental preference, heterogeneity and human capital inequality. Economic Development and Cultural Change 53 (2), 381-407.

Bacolod, M. P., Ranjan, P., 2008. Why children work, attend school or stay idle: The roles of ability and household wealth. Economic Development and Cultural Change 56 (4), 791-828.

Becker, G. S., Tomes, N., 1976. Child endowments and the quantity and quality of children. Journal of Political Economy 84 (4), S143-S162.

Behrman, J. R., 1997. Intrahousehold distribution and the family. In Rosenzweig, M. R., Stark, O. (Eds.), Handbook of Population and Family Economics. vol. 1A. Elsevier, Amsterdam, pp. 125187.

Behrman, J. R., Deolalikar, A. B., 1995. Are there differential returns to schooling by gender? The case of Indonesian labor markets. Oxford Bulletin of Economics and Statistics 57 (1), 97-118.

Behrman, J. R., Pollack, R. A., Taubman, P., 1982. Parental preferences and provision for progeny. Journal of Political Economy 90 (1), 52-73.

Biggeri, M., Guarcello, L., Lyon, S., Rosati, F. C., 2003. The puzzle of 'Idle' children: Neither in school nor performing economic activity: Evidence from six countries. Understanding Children's Work (UCW) working paper (November), University of Rome.

Campbell, J., 1998. Review of the Peabody Picture Vocabulary Test - Third edition. Journal of Psychoeducational Assessment 16 (4), 334-338.

Campbell, J., Bell, S. K., Keith, L. K., 2001. Concurrent validity of the Peabody Picture Vocabulary Test - third edition as an intelligence and achievement screener for low SES African American children. Assessment 8 (1), 85-94.

Central Statistical Agency (CSA), 2003. Ethiopia child labor survey report 2001: Statistical bulletin 262. Ministry of Labor and Social Affairs, International Labor Organization, Addis Ababa.

Cueto, S., Leon, J., Guerrero, G., Munoz, I., 2009. Psychometric characteristics of cognitive development and achievement instruments in round 2 of Young Lives. Young Lives Technical Note No. 15, Young Lives, UK.

Cueto, S., Leon, J., 2012. Psychometric characteristics of cognitive development and achievement instruments in round 3 of Young Lives. Young Lives Technical Note No. 25, Young Lives, UK. 
Dercon, S., Singh, A., 2013. From nutrition to aspirations and self-efficacy: Gender bias over time among children in four countries. World Development 45, 31-50.

Dunn, L. M., Dunn, L. M., 1997. Peabody Picture Vocabulary Test, Third Edition. Circle Pines, $\mathrm{MN}$ : American Guidance Service.

Edmonds, E. V., 2008. Child labor. In Strauss, J., Schultz, T. P. (Eds.), Handbook of Development Economics. Elsevier, Amsterdam, pp. 3607-3709.

Filmer, D., Pritchett, L., 1999. The effect of household wealth on educational attainment: Demographic and Health Survey evidence. World Bank Policy Research Working Paper No. 1980, World Bank.

Frost, M., Little, A. W., 2014. Children's learning practices in Ethiopia: Observations from primary school classes. Oxford Review of Education 40 (1), 91-111.

Garg, A., Morduch, J., 1998. Sibling rivalry and the gender gap: Evidence from child health outcomes in Ghana. Journal of Population Economics 11 (4), 471-493.

Glewwe, P., Jacoby, H. G., King, E. M., 2001. Early childhood nutrition and academic achievement: A longitudinal analysis. Journal of Public Economics 81 (3), 345-368.

Glick, P., Sahn, D., 2010. Early academic performance, grade repetition and school attainment in Senegal: A panel data analysis. World Bank Economic Review 24 (1), 93-120.

Grantham-McGregor, S., Cheung, Y. B., Cueto, S., Glewwe, P., Richter, L., Strupp, B., 2007.

Child development in developing countries 1: Developmental potential in the first 5 years for children in developing countries. Lancet 369 (9555), 60-70.

Haveman, R., Wolfe, B., 1995. The determinants of children's attainments: A review of methods and findings. Journal of Economic Literature 33 (4), 1829-1878.

Helmers, C., Patnam, M., 2011. The formation and evolution of childhood skill acquisition: Evidence from India. Journal of Development Economics 95 (2), 252-266.

Himaz, R., 2013. Impact of parental death in middle childhood and adolescence on child outcomes. Journal of African Economies 22 (3), 463-490.

Honoré, B. E., 1992. Trimmed lad and least squares estimation of truncated and censored regression models with fixed effects. Econometrica 60 (3), 533-565.

Kim, C., 2009. Is combining child labor and school education the right approach? Investigating the Cambodian case. International Journal of Educational Development 29 (1), 30-38.

Liddell, C., Rae, G., 2001. Predicting early grade retention: A longitudinal investigation of primary school progress in a sample of rural South African children. British Journal of Educational Psychology 71 (3), 413-428. 
Nichols, A., Schaffer, M. E., 2007. Clustered standard errors in Stata. United Kingdom Stata Users' Group Meetings 09, Stata Users Group.

Orkin, K., 2010. In the child's best interests? Legislation on children's work in Ethiopia. Journal of International Development 22 (8), 1102-1114.

Orkin, K., 2012. Are work and schooling complimentary or competitive for children in rural Ethiopia? A mixed-methods study. In Boyden, J., Bourdillon, M. (Eds.), Childhood Poverty: Multidisciplinary Approaches. Palgrave Macmillan, London, pp. 298-313.

Outes-Leon, I., Sanchez, A., 2008. An assessment of the Young Lives sampling approach in Ethiopia. Young Lives Technical Note No. 1, Young Lives, UK.

Patrinos, H. A., Psacharopoulos, G., 1997. Family size, schooling and child labor in Peru - An empirical analysis. Journal of Population Economics 10 (4), 387-405.

Pitt, M. M., Rosenzweig, M. R., Hassan, M. N., 1990. Productivity, health and inequality in the intrahousehold distribution of food in low-income countries. American Economic Review 80 (5), 240-244.

Ravallion, M., Wodon, Q. T., 2000. Does child labor displace schooling? Evidence on behavioral responses to an enrollment subsidy. Economic Journal 110 (462), 158-175.

Rolleston, C., 2014. Learning profiles and the 'skills gap': A comparative analysis of schooling and skills development in four developing countries. Oxford Review of Education 40 (1), 132150.

Rosenzweig, M. R., Schultz, T. P., 1982. Market opportunities, genetic endowments, and intrafamily resource distribution: Child survival in rural India. American Economic Review 72 (4), 803-815.

Sanchez, A., 2009. Early nutrition and cognitive achievement in pre-school children in Peru. Young Lives Working Paper 57, Oxford.

Stith, A. Y., Gorman, K. S., Choudhury, N., 2003. The effects of psychosocial risk and gender on school attainment in Guatemala. Applied Psychology: An International Review 52 (4), 614-629.

Strauss, J., Thomas, D., 1998. Health, nutrition, and economic development. Journal of Economic Literature 36 (2), 766-817.

Sun, A., Yao, Y., 2010. Health shocks and children's school attainments in rural China. Economics of Education Review 29 (3), 375-382.

Woldehanna, T. 2011a. Children's educational completion rates and dropouts in the context of Ethiopia's national poverty reduction strategy. Ethiopian Journal of Economics 20 (1), 25-53.

Woldehanna, T., 2011b. The effects of early childhood education attendance on cognitive development: Evidence from urban Ethiopia. Ethiopian Journal of Economics 20(1), 113-164. 
Woldehanna, T., Jones, N., Tefera, B., 2008a. The invisibility of children's paid and unpaid work: Implications for Ethiopia's national poverty reduction policy. Childhood 15(2), 177-201.

Woldehanna, T., Mekonnen, A., Jones, N., 2008b. Education choices in Ethiopia: What determines whether poor households send their children to school? Ethiopian Journal of Economics 17(1), 43-80.

World Bank, 2005. Education in Ethiopia: Strengthening the foundation for sustainable progress, World Bank, Washington, D.C.

World Bank, 2013. World Development Indicators (http://data.worldbank.org/datacatalog/world-development-indicators)

Table 1a: Summary Statistics: Basic Child and Household Variables

\begin{tabular}{lcccc}
\hline & Age 12 & & Age 15 \\
\cline { 2 - 2 } Female & Mean (Std. dev.) & & Mean (Std. dev.) \\
Age in months & 0.49 & & \\
& $144.65(3.81)$ & & $179.84(3.60)$
\end{tabular}




\begin{tabular}{|c|c|c|}
\hline Mother's schoolinga & $2.20(3.64)$ & $2.19(3.62)$ \\
\hline Father's schoolinga & $3.30(4.42)$ & $3.33(4.41)$ \\
\hline Caregiver's age & $39.39(9.56)$ & $41.95(9.51)$ \\
\hline Head's age & $46.62(11.35)$ & $48.72(11.54)$ \\
\hline Other caregiver ${ }^{\mathrm{b}}$ & 0.13 & 0.13 \\
\hline Female head & 0.26 & 0.27 \\
\hline Household size & $6.52(2.05)$ & $6.35(2.12)$ \\
\hline Number of adults & $3.51(1.67)$ & $4.44(2.09)$ \\
\hline Number of siblings & $3.25(1.93)$ & $3.02(1.88)$ \\
\hline Number of sisters & $1.58(1.30)$ & $1.45(1.26)$ \\
\hline Number of children $<5$ & $0.59(0.74)$ & $0.47(0.65)$ \\
\hline Child's birth order & $4.00(2.56)$ & \\
\hline Wealth indexc & $0.30(0.17)$ & $0.35(0.17)$ \\
\hline Nondurable PCE ${ }^{\mathrm{d}}$ & $4.73(0.58)$ & $4.82(0.57)$ \\
\hline \multicolumn{3}{|l|}{ Child's healthe } \\
\hline Same as peers & 0.61 & 0.48 \\
\hline Better than peers & 0.28 & 0.44 \\
\hline Worse than peers & 0.11 & 0.08 \\
\hline Child had serious illness/injury & 0.16 & 0.14 \\
\hline \multicolumn{3}{|l|}{ Household health shocks ${ }^{f}$} \\
\hline Father's illness & 0.15 & 0.15 \\
\hline Mother's illness & 0.20 & 0.22 \\
\hline Household member's illness & 0.20 & 0.25 \\
\hline Urban & 0.40 & 0.42 \\
\hline Observations & 971 & \\
\hline
\end{tabular}

Notes:

a Refers to that of biological mother's and father's. The biological mother is also the caregiver for 88 percent of the base observations. When biological parent/s is absent, parents' schooling reflects the caregiver's and partner's (i.e. mother/father figure's) education. Observations that have still missing information for either parent's schooling are assigned a value of zero.

${ }^{b}$ Refers to children whose caregiver is neither the biological mother nor the biological father.

c $0-1$ index constructed based on component indices for housing quality, consumer durables/assets, and services.

${ }^{\mathrm{d}}$ Log of monthly total real (base 2006) nondurable consumption (food plus nonfood) expenditure per adult.

e Based on child's assessment of own health relative to other children of the same age.

${ }^{\mathrm{f}}$ Based on a question about some of the most important events that negatively affected the household's economy since the previous round.

Table 1b: Summary Statistics: Measures of Ability

\begin{tabular}{lcccccc}
\hline & Obs. & Min. & Max. & Median & Mean & Std. dev. \\
\hline Age 12: PPVTa & 945 & 11 & 127 & 72 & 75.88 & 26.18 \\
Age 15: PPVT & 971 & 38 & 203 & 161 & 151.91 & 34.26 \\
\hline
\end{tabular}

Notes: Statistics are based on raw scores. 
a PPVT - Peabody Picture Vocabulary Test

Table 1c: Summary Statistics: Children's School Enrollment, Work Status and Work Hours

\begin{tabular}{llllll}
\hline & \multicolumn{2}{c}{ Age 12 } & & \multicolumn{2}{c}{ Age 15 } \\
\cline { 2 - 3 } \cline { 5 - 6 } & Obs. & Mean (SD) & & Obs. & Mean (SD) \\
\hline Schooling & & & & & \\
$\quad$ Ever enrolled & 971 & 0.97 & & 971 & 0.99 \\
$\quad$ Currently enrolled & 971 & 0.95 & & 971 & 0.90 \\
$\quad$ Grade completed & 945 & $3.25(1.63)$ & & 964 & $5.55(2.05)$ \\
$\quad$ Work & & & & \\
$\quad$ Work status & 970 & 0.48 & & 970 & 0.46 \\
$\quad$ Work hours & 465 & $3.28(1.79)$ & & 444 & $3.80(2.38)$ \\
\hline
\end{tabular}

Notes:

Ever enrolled - dummy for whether the child ever attended formal school.

Currently enrolled - dummy for whether the child is currently (as of survey date) enrolled in school.

Grade completed - highest grade completed as of survey date by ever enrolled child.

a Based on reported child's time-use during a typical day in the week prior to survey date.

Work status - equals one if child reported non-zero hours in work for pay or on family farm/business, zero otherwise.

Work hours - hours of work for pay or on family farm/business on a typical day in the week prior to the survey; statistics are conditional on participation.

Table 1d: Self- and Caregiver-reported Primary Reasons for School Non-enrollment

\begin{tabular}{llllll}
\hline \multirow{2}{*}{ Reason } & \multicolumn{2}{c}{ Age 12 } & & \multicolumn{2}{c}{ Age 15 } \\
\cline { 2 - 3 } & Child & Caregiver nnnnyyyn & & Child & Caregiver \\
\hline Financial problems & $7(14.3 \%)$ & $4(8.2 \%)$ & & $10(10.1 \%)$ & $9(9.1 \%)$
\end{tabular}


School too far or unsafe to travel to

\begin{tabular}{llll}
$2(4.1 \%)$ & $2(4.1 \%)$ & $2(2 \%)$ & $1(1 \%)$ \\
$5(10.2 \%)$ & $5(10.2 \%)$ & $9(9.1 \%)$ & $19(19.2 \%)$ \\
$1(2 \%)$ & $1(2 \%)$ & & \\
$4(8.2 \%)$ & $3(6.1 \%)$ & $3(3 \%)$ & $2(2 \%)$ \\
$2(4.1 \%)$ & $1(2 \%)$ & & $1(1 \%)$ \\
$14(28.6 \%)$ & $15(30.6 \%)$ & $39(39.4 \%)$ & $39(39.4 \%)$ \\
$6(12.2 \%)$ & $6(12.2 \%)$ & $8(8.1 \%)$ & $9(9.1 \%)$ \\
$2(4.1 \%)$ & $1(2 \%)$ & $5(5.1 \%)$ & $2(2 \%)$ \\
$1(2 \%)$ & $2(4.1 \%)$ & $5(5.1 \%)$ & $7(7.1 \%)$ \\
$5(10.2 \%)$ & $9(18.4 \%)$ & $18(18.2 \%)$ & $10(10.1 \%)$ \\
\multicolumn{3}{c}{99} \\
\hline
\end{tabular}

Lack of interest or behavioral problems

Poor quality education/school facilities

Schooling not needed for job/trade

To look after siblings

To work for household or for pay

Illness

To look after ill or elderly family members

Family issues or conflict

Other or reason not given

Observations 


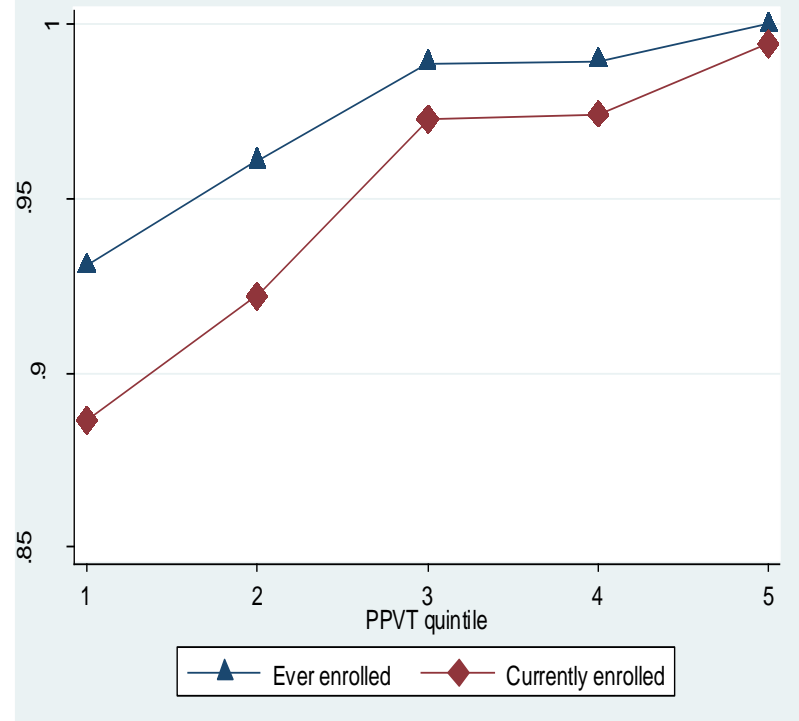

Figure 1.1: School status by test score quintile, Age 12

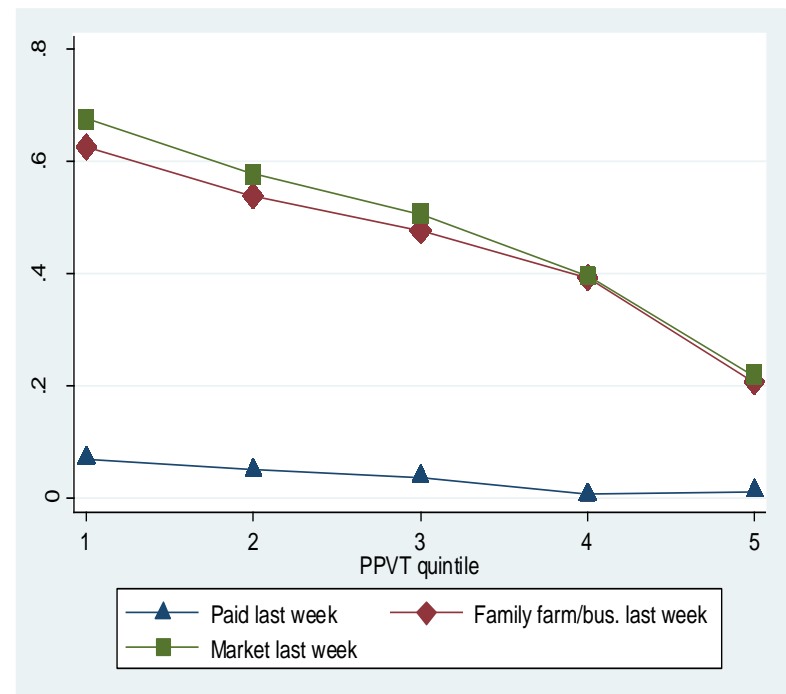

Figure 2.1: Participation in work, by type of work and test score quintile, Age 12

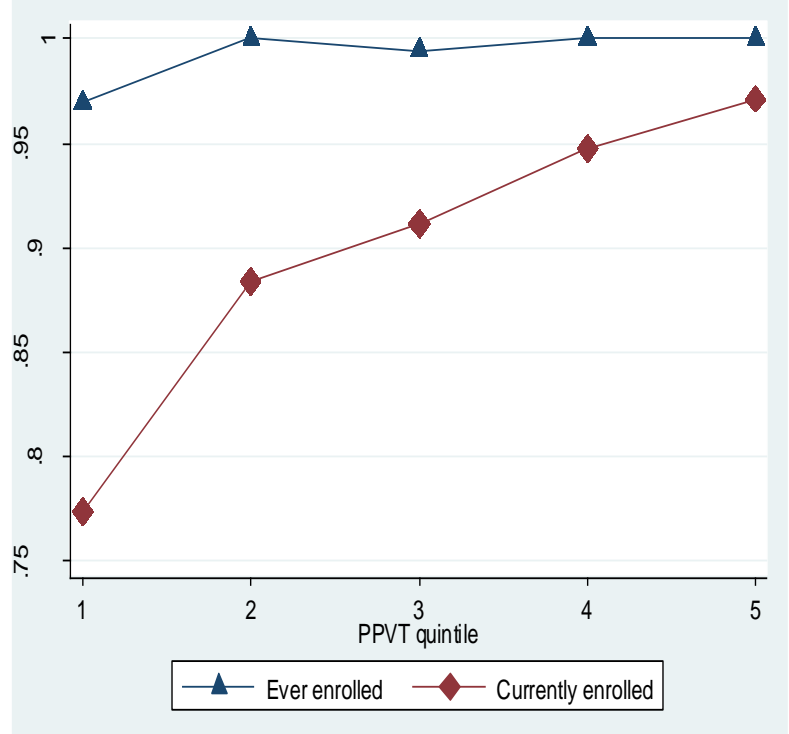

Figure 1.2: School status by test score quintile, Age 15

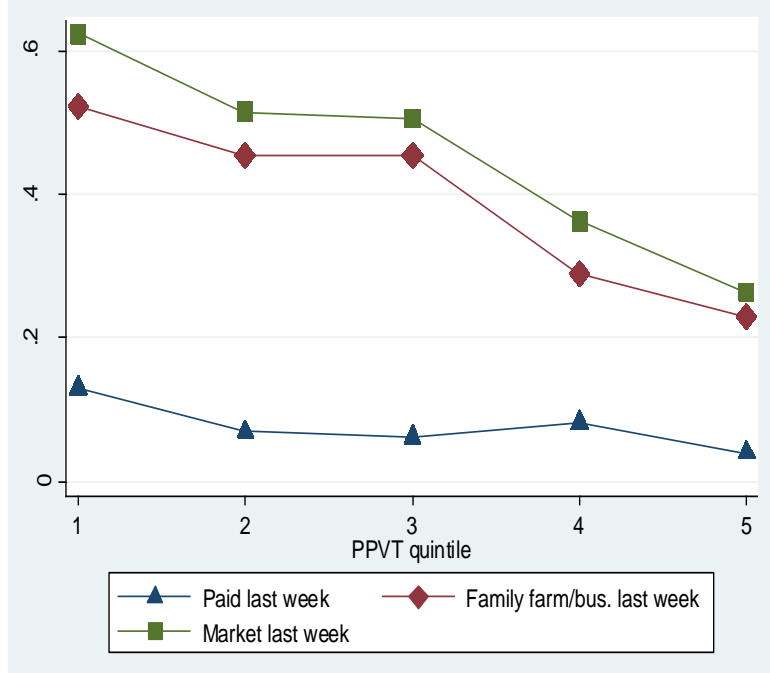

Figure 2.2: Participation in work, by type of work and test score quintile, Age 15 


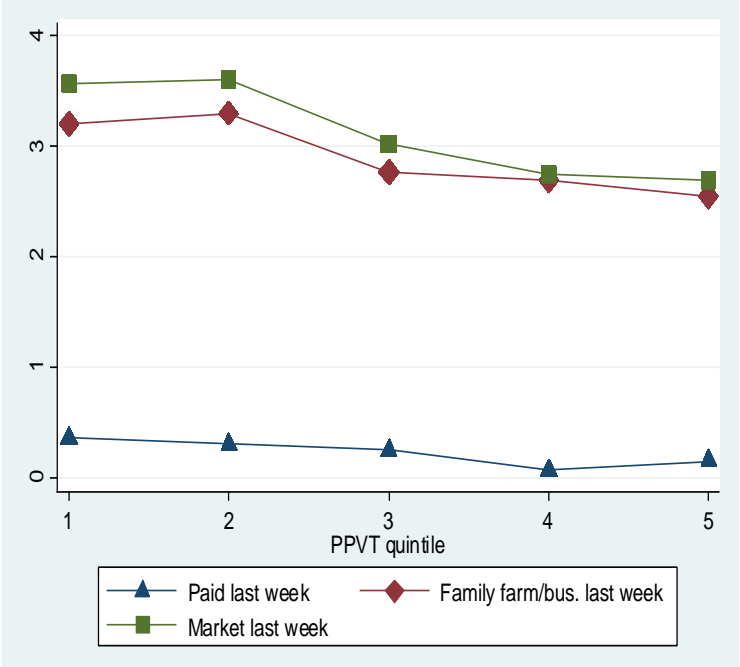

Figure 2.3: Hours of work, by type of work and test score quintile, Age 12

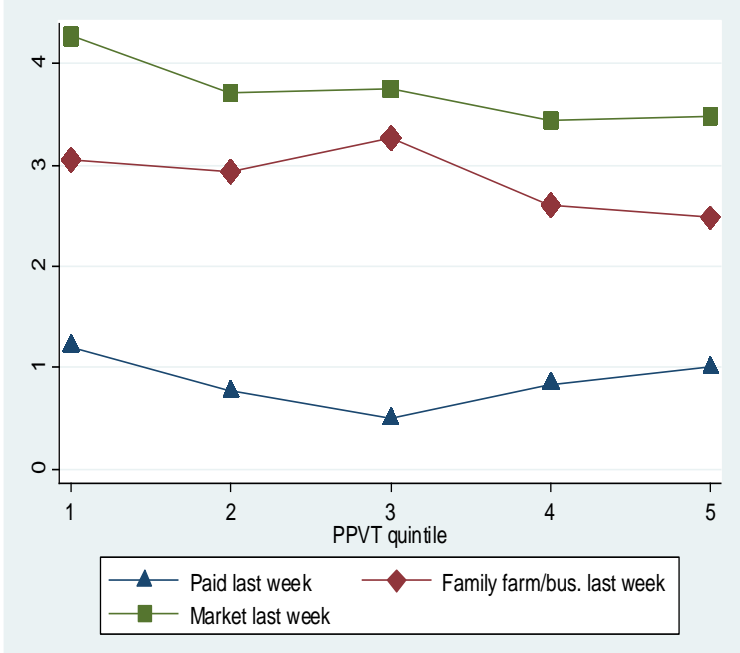

Figure 2.4: Hours of work, by type of work and test score quintile, Age 15 
Table 2: Children's endowment and school enrollment

\begin{tabular}{|c|c|c|c|c|}
\hline \multirow{2}{*}{ Female } & \multicolumn{2}{|c|}{ Age 12} & \multicolumn{2}{|c|}{ Age 15} \\
\hline & 0.030 & 0.029 & $0.061 * * *$ & $0.057 * * *$ \\
\hline & $(1.12)$ & $(1.12)$ & $(2.75)$ & $(3.04)$ \\
\hline \multirow[t]{2}{*}{ PPVT } & $0.027^{* *}$ & $0.038^{* *}$ & $0.065^{* * *}$ & $0.057 * * *$ \\
\hline & $(2.43)$ & $(2.24)$ & $(4.01)$ & $(2.93)$ \\
\hline \multirow[t]{2}{*}{ PPVT squared } & & -0.009 & & $-0.024^{* *}$ \\
\hline & & $(0.78)$ & & $(2.09)$ \\
\hline \multirow[t]{2}{*}{ Female $\times$ PPVT } & & -0.024 & & -0.036 \\
\hline & & $(1.15)$ & & $(1.22)$ \\
\hline \multirow[t]{2}{*}{ Mother's schooling } & -0.000 & 0.000 & $-0.005^{*}$ & -0.004 \\
\hline & $(0.07)$ & $(0.03)$ & $(1.80)$ & $(1.62)$ \\
\hline \multirow[t]{2}{*}{ Father's schooling } & -0.002 & -0.002 & 0.002 & 0.002 \\
\hline & $(0.95)$ & $(0.94)$ & $(0.77)$ & $(0.73)$ \\
\hline \multirow[t]{2}{*}{ Caregiver's age } & -0.000 & -0.000 & 0.001 & 0.001 \\
\hline & $(0.00)$ & $(0.11)$ & $(0.49)$ & $(0.58)$ \\
\hline \multirow[t]{2}{*}{ Head's age } & 0.001 & 0.001 & 0.002 & 0.002 \\
\hline & $(0.86)$ & $(0.89)$ & $(1.17)$ & $(1.20)$ \\
\hline \multirow[t]{2}{*}{ Other caregiver } & $-0.056^{*}$ & $-0.057^{*}$ & $-0.054^{*}$ & $-0.050^{*}$ \\
\hline & $(1.90)$ & $(1.95)$ & $(1.83)$ & $(1.81)$ \\
\hline \multirow[t]{2}{*}{ Female head } & 0.029 & 0.030 & 0.015 & 0.013 \\
\hline & $(1.13)$ & $(1.13)$ & $(0.42)$ & $(0.39)$ \\
\hline \multirow[t]{2}{*}{ Number of adults } & -0.009 & -0.008 & -0.003 & -0.003 \\
\hline & $(1.32)$ & $(1.21)$ & $(0.66)$ & $(0.78)$ \\
\hline \multirow[t]{2}{*}{ Number of siblings } & $0.011^{*}$ & $0.011^{*}$ & $0.017^{*}$ & $0.017^{*}$ \\
\hline & $(1.93)$ & $(1.86)$ & $(1.95)$ & $(1.84)$ \\
\hline \multirow[t]{2}{*}{ Number of sisters } & -0.000 & -0.001 & -0.006 & -0.006 \\
\hline & $(0.04)$ & $(0.15)$ & $(0.51)$ & $(0.48)$ \\
\hline \multirow[t]{2}{*}{ Number of children $<5$} & $-0.020^{* *}$ & $-0.020^{* *}$ & -0.013 & -0.014 \\
\hline & $(2.36)$ & $(2.28)$ & $(1.14)$ & $(1.14)$ \\
\hline \multirow[t]{2}{*}{ Child's birth order } & $-0.008^{*}$ & $-0.008^{*}$ & $-0.014^{* * *}$ & $-0.013^{* *}$ \\
\hline & $(1.93)$ & $(1.90)$ & $(2.69)$ & $(2.65)$ \\
\hline \multirow[t]{2}{*}{ Household wealth } & 0.020 & 0.022 & $0.047^{* * *}$ & $0.049^{* * *}$ \\
\hline & $(1.11)$ & $(1.24)$ & $(3.40)$ & $(3.55)$ \\
\hline \multirow[t]{2}{*}{ Nondurable PCE } & -0.008 & -0.008 & 0.022 & 0.024 \\
\hline & $(0.47)$ & $(0.44)$ & $(0.93)$ & (1.03) \\
\hline \multirow[t]{2}{*}{ Health better than peers } & -0.019 & -0.019 & $0.038^{*}$ & $0.038^{*}$ \\
\hline & $(1.36)$ & $(1.38)$ & $(2.01)$ & $(1.96)$ \\
\hline \multirow[t]{2}{*}{ Health worse than peers } & $-0.085^{* *}$ & $-0.083^{* *}$ & -0.007 & -0.017 \\
\hline & $(2.17)$ & $(2.16)$ & $(0.16)$ & $(0.37)$ \\
\hline \multirow[t]{2}{*}{ Had serious illness/injury } & -0.019 & -0.019 & -0.003 & -0.003 \\
\hline & $(1.22)$ & $(1.05)$ & $(0.10)$ & $(0.11)$ \\
\hline \multirow[t]{2}{*}{ Father ill } & 0.017 & 0.017 & 0.013 & 0.013 \\
\hline & $(1.01)$ & $(0.98)$ & $(0.46)$ & $(0.46)$ \\
\hline Mother ill & -0.017 & -0.016 & 0.001 & 0.002 \\
\hline
\end{tabular}




\begin{tabular}{lllll} 
& $(0.72)$ & $(0.67)$ & $(0.03)$ & $(0.05)$ \\
Household member ill & -0.004 & -0.004 & 0.021 & 0.022 \\
& $(0.25)$ & $(0.21)$ & $(0.88)$ & $(0.96)$ \\
Constant & $0.958^{* * *}$ & $0.963^{* * *}$ & $0.586^{* * *}$ & $0.597^{* * *}$ \\
& $(11.48)$ & $(11.50)$ & $(4.36)$ & $(4.63)$ \\
Community fixed effects & Yes & Yes & Yes & Yes \\
Observations & 945 & 945 & 971 & 971 \\
Adjusted R ${ }^{2}$ & 0.06 & 0.06 & 0.12 & 0.13 \\
\hline
\end{tabular}

Notes: Dependent variable: School enrollment. Coefficients from a linear probability model are reported. $|\mathrm{t}|$ ratios are shown in parentheses and are based on standard errors that are robust to arbitrary heteroscedasticity and clustering at the site/community level. ${ }^{* *}$-shows significance at $1 \%$; **-shows significance at $5 \%$; ${ }^{*}$-shows significance at $10 \%$. 
Table 3: Children's endowment and participation in work

\begin{tabular}{|c|c|c|c|c|}
\hline \multirow[b]{2}{*}{ Female } & \multicolumn{2}{|c|}{ Age 12} & \multicolumn{2}{|c|}{ Age 15} \\
\hline & $\begin{array}{l}-0.240^{* * *} \\
(4.95)\end{array}$ & $\begin{array}{l}-0.239^{* * *} \\
(5.33)\end{array}$ & $\begin{array}{l}-0.405^{* * *} \\
(6.94)\end{array}$ & $\begin{array}{l}-0.404^{* * *} \\
(7.61)\end{array}$ \\
\hline PPVT & $\begin{array}{l}-0.033^{*} \\
(1.79)\end{array}$ & $\begin{array}{l}-0.052^{*} \\
(1.98)\end{array}$ & $\begin{array}{l}-0.056^{* * *} \\
(2.92)\end{array}$ & $\begin{array}{l}-0.086^{* * *} \\
(3.82)\end{array}$ \\
\hline PPVT squared & & $\begin{array}{l}0.017 \\
(1.12)\end{array}$ & & $\begin{array}{l}0.006 \\
(0.57)\end{array}$ \\
\hline Female $\times$ PPVT & & $\begin{array}{l}0.041 \\
(1.41)\end{array}$ & & $\begin{array}{l}0.074^{* *} \\
(2.10)\end{array}$ \\
\hline Mother's schooling & $\begin{array}{l}-0.001 \\
(0.15)\end{array}$ & $\begin{array}{l}-0.001 \\
(0.24)\end{array}$ & $\begin{array}{l}-0.007 \\
(1.21)\end{array}$ & $\begin{array}{l}-0.008 \\
(1.33)\end{array}$ \\
\hline Father's schooling & $\begin{array}{l}-0.004 \\
(1.07)\end{array}$ & $\begin{array}{l}-0.004 \\
(1.09)\end{array}$ & $\begin{array}{l}0.001 \\
(0.10)\end{array}$ & $\begin{array}{l}0.001 \\
(0.13)\end{array}$ \\
\hline Caregiver's age & $\begin{array}{l}-0.004^{* * *} \\
(3.37)\end{array}$ & $\begin{array}{l}-0.004^{* * *} \\
(3.37)\end{array}$ & $\begin{array}{l}-0.000 \\
(0.22)\end{array}$ & $\begin{array}{l}-0.001 \\
(0.34)\end{array}$ \\
\hline Head's age & $\begin{array}{l}0.005^{* * *} \\
(3.56)\end{array}$ & $\begin{array}{l}0.005^{* * *} \\
(3.46)\end{array}$ & $\begin{array}{l}0.002 \\
(1.40)\end{array}$ & $\begin{array}{l}0.003 \\
(1.50)\end{array}$ \\
\hline Other caregiver & $\begin{array}{l}0.080^{* *} \\
(2.42)\end{array}$ & $\begin{array}{l}0.082^{* *} \\
(2.45)\end{array}$ & $\begin{array}{l}-0.009 \\
(0.26)\end{array}$ & $\begin{array}{l}-0.014 \\
(0.42)\end{array}$ \\
\hline Female head & $\begin{array}{l}-0.051 \\
(1.52)\end{array}$ & $\begin{array}{l}-0.052^{*} \\
(1.57)\end{array}$ & $\begin{array}{l}0.008 \\
(0.33)\end{array}$ & $\begin{array}{l}0.010 \\
(0.41)\end{array}$ \\
\hline Number of adults & $\begin{array}{l}0.012 \\
(1.35)\end{array}$ & $\begin{array}{l}0.010 \\
(1.22)\end{array}$ & $\begin{array}{l}0.006 \\
(0.78)\end{array}$ & $\begin{array}{l}0.006 \\
(0.83)\end{array}$ \\
\hline Number of siblings & $\begin{array}{l}-0.002 \\
(0.12)\end{array}$ & $\begin{array}{l}-0.001 \\
(0.09)\end{array}$ & $\begin{array}{l}-0.004 \\
(0.43)\end{array}$ & $\begin{array}{l}-0.002 \\
(0.24)\end{array}$ \\
\hline Number of sisters & $\begin{array}{l}0.030^{* *} \\
(2.41)\end{array}$ & $\begin{array}{l}0.032 * * \\
(2.44)\end{array}$ & $\begin{array}{l}0.003 \\
(0.24)\end{array}$ & $\begin{array}{l}-0.000 \\
(0.01)\end{array}$ \\
\hline Number of children $<5$ & $\begin{array}{l}-0.010 \\
(0.54)\end{array}$ & $\begin{array}{l}-0.010 \\
(0.56)\end{array}$ & $\begin{array}{l}-0.015 \\
(0.52)\end{array}$ & $\begin{array}{l}-0.015 \\
(0.50)\end{array}$ \\
\hline Child's birth order & $\begin{array}{l}-0.004 \\
(0.70)\end{array}$ & $\begin{array}{l}-0.004 \\
(0.68)\end{array}$ & $\begin{array}{l}-0.004 \\
(0.52)\end{array}$ & $\begin{array}{l}-0.005 \\
(0.62)\end{array}$ \\
\hline Household wealth & $\begin{array}{l}-0.056^{*} \\
(1.90)\end{array}$ & $\begin{array}{l}-0.059 * * \\
(2.08)\end{array}$ & $\begin{array}{l}-0.034 \\
(1.23)\end{array}$ & $\begin{array}{l}-0.036 \\
(1.30)\end{array}$ \\
\hline Nondurable PCE & $\begin{array}{l}0.052 \\
(1.62)\end{array}$ & $\begin{array}{l}0.051 \\
(1.63)\end{array}$ & $\begin{array}{l}-0.050 * * \\
(2.27)\end{array}$ & $\begin{array}{l}-0.050 * * \\
(2.34)\end{array}$ \\
\hline Health better than peers & $\begin{array}{l}-0.047 \\
(1.50)\end{array}$ & $\begin{array}{l}-0.047 \\
(1.56)\end{array}$ & $\begin{array}{l}-0.073^{* * *} \\
(3.77)\end{array}$ & $\begin{array}{l}-0.074^{* * *} \\
(4.09)\end{array}$ \\
\hline Health worse than peers & $\begin{array}{l}-0.083 \\
(1.58)\end{array}$ & $\begin{array}{l}-0.086 \\
(1.66)\end{array}$ & $\begin{array}{l}-0.115^{* *} \\
(2.24)\end{array}$ & $\begin{array}{l}-0.104^{* *} \\
(2.08)\end{array}$ \\
\hline Had serious illness/injury & $\begin{array}{l}0.018 \\
(0.70)\end{array}$ & $\begin{array}{l}0.016 \\
(0.65)\end{array}$ & $\begin{array}{l}-0.043 \\
(1.35)\end{array}$ & $\begin{array}{l}-0.042 \\
(1.34)\end{array}$ \\
\hline Father ill & $\begin{array}{l}-0.033 \\
(0.76)\end{array}$ & $\begin{array}{l}-0.032 \\
(0.74)\end{array}$ & $\begin{array}{l}0.043 \\
(1.18)\end{array}$ & $\begin{array}{l}0.046 \\
(1.26)\end{array}$ \\
\hline Mother ill & -0.026 & -0.028 & $-0.052^{*}$ & $-0.053^{*}$ \\
\hline
\end{tabular}




\begin{tabular}{|c|c|c|c|c|}
\hline & $(0.90)$ & $(0.94)$ & $(1.72)$ & $(1.80)$ \\
\hline \multirow[t]{2}{*}{ Household member ill } & -0.001 & -0.002 & -0.005 & -0.007 \\
\hline & $(0.03)$ & $(0.06)$ & $(0.20)$ & $(0.28)$ \\
\hline \multirow[t]{2}{*}{ Constant } & $0.367^{* *}$ & $0.359^{* *}$ & $0.934^{* * *}$ & $0.934^{* * *}$ \\
\hline & $(2.35)$ & $(2.35)$ & $(7.04)$ & $(7.26)$ \\
\hline Community fixed & Yes & Yes & Yes & Yes \\
\hline Observations & 944 & 944 & 970 & 970 \\
\hline Adjusted R² & 0.40 & 0.40 & 0.35 & 0.36 \\
\hline
\end{tabular}

Notes: Dependent variable: Participation in work. Coefficients from a linear probability model are reported. $|t|$ ratios are shown in parentheses and are based on standard errors that are robust to arbitrary heteroscedasticity and clustering at the site/community level. ${ }^{* *}$-shows significance at $1 \%$; ${ }^{* *}$-shows significance at $5 \%$; ${ }^{*}$-shows significance at $10 \%$. 
Table 4: Children's endowment and work hours




(5.71)

Community fixed effects

Observations

Pseudo R2 (Prob. > Chi ${ }^{2}$ )
No

944

0.15
(2.57)

No Yes

$970 \quad 970$

0.13

0.00

Notes: Dependent variable: Hours of work.

a - Marginal effects (conditional) from a tobit model are reported. $|z|$ ratios based on robust standard errors are shown in parentheses. The tobit regressions also included regional dummies and a constant.

b - Coefficients from Honoré's (1992) semiparametric censored fixed effects model are reported. $|\mathrm{z}|$ ratios based on bootstrapped standard errors are shown in parentheses.

***-shows significance at $1 \% ;{ }^{* *}$-shows significance at $5 \%$; ${ }^{*}$-shows significance at $10 \%$. 
Table 5: Children's endowment and school enrollment: Endowment measured as residual

\begin{tabular}{|c|c|c|c|c|}
\hline \multirow[b]{2}{*}{ Female } & \multicolumn{2}{|c|}{ Age 12} & \multicolumn{2}{|c|}{ Age 15} \\
\hline & $\begin{array}{l}0.033 \\
(1.27)\end{array}$ & $\begin{array}{l}0.033 \\
(1.32)\end{array}$ & $\begin{array}{l}0.049^{* *} \\
(2.17)\end{array}$ & $\begin{array}{l}0.050^{* * *} \\
(2.73)\end{array}$ \\
\hline Residual PPVT & $\begin{array}{l}0.002^{* * *} \\
(4.78)\end{array}$ & $\begin{array}{l}0.002^{* * *} \\
(2.60)\end{array}$ & $\begin{array}{l}0.003^{* * *} \\
(5.02)\end{array}$ & $\begin{array}{l}0.003^{* * *} \\
(3.53)\end{array}$ \\
\hline Residual PPVT squared & & $\begin{array}{l}-0.000 \\
(0.54)\end{array}$ & & $\begin{array}{l}-0.003 \times 10^{-2 * *} \\
(2.01)\end{array}$ \\
\hline Female $\times$ Residual PPVT & & $\begin{array}{l}-0.000 \\
(0.30)\end{array}$ & & $\begin{array}{l}-0.001 \\
(1.24)\end{array}$ \\
\hline Mother's schooling & $\begin{array}{l}0.001 \\
(0.86)\end{array}$ & $\begin{array}{l}0.001 \\
(0.84)\end{array}$ & $\begin{array}{l}-0.003 \\
(1.20)\end{array}$ & $\begin{array}{l}-0.004 \\
(1.41)\end{array}$ \\
\hline Father's schooling & $\begin{array}{l}-0.000 \\
(0.17)\end{array}$ & $\begin{array}{l}-0.000 \\
(0.21)\end{array}$ & $\begin{array}{l}0.004 \\
(1.51)\end{array}$ & $\begin{array}{l}0.003 \\
(1.32)\end{array}$ \\
\hline Caregiver's age & $\begin{array}{l}0.000 \\
(0.21)\end{array}$ & $\begin{array}{l}0.000 \\
(0.11)\end{array}$ & $\begin{array}{l}0.001 \\
(0.71)\end{array}$ & $\begin{array}{l}0.001 \\
(0.71)\end{array}$ \\
\hline Head's age & $\begin{array}{l}0.001 \\
(0.85)\end{array}$ & $\begin{array}{l}0.001 \\
(0.85)\end{array}$ & $\begin{array}{l}0.001 \\
(1.22)\end{array}$ & $\begin{array}{l}0.001 \\
(1.27)\end{array}$ \\
\hline Other caregiver & $\begin{array}{l}-0.060^{* *} \\
(2.36)\end{array}$ & $\begin{array}{l}-0.058^{* *} \\
(2.33)\end{array}$ & $\begin{array}{l}-0.065^{* *} \\
(2.09)\end{array}$ & $\begin{array}{l}-0.057^{* *} \\
(2.01)\end{array}$ \\
\hline Female head & $\begin{array}{l}0.015 \\
(0.72)\end{array}$ & $\begin{array}{l}0.016 \\
(0.74)\end{array}$ & $\begin{array}{l}0.014 \\
(0.45)\end{array}$ & $\begin{array}{l}0.014 \\
(0.45)\end{array}$ \\
\hline Number of adults & $\begin{array}{l}-0.007 \\
(1.34)\end{array}$ & $\begin{array}{l}-0.007 \\
(1.34)\end{array}$ & $\begin{array}{l}-0.003 \\
(0.66)\end{array}$ & $\begin{array}{l}-0.003 \\
(0.71)\end{array}$ \\
\hline Number of siblings & $\begin{array}{l}0.010^{*} \\
(1.85)\end{array}$ & $\begin{array}{l}0.010^{* *} \\
(1.92)\end{array}$ & $\begin{array}{l}0.016^{* *} \\
(2.03)\end{array}$ & $\begin{array}{l}0.018^{* *} \\
(2.31)\end{array}$ \\
\hline Number of sisters & $\begin{array}{l}0.000 \\
(0.04)\end{array}$ & $\begin{array}{l}0.000 \\
(0.00)\end{array}$ & $\begin{array}{l}-0.004 \\
(0.38)\end{array}$ & $\begin{array}{l}-0.005 \\
(0.43)\end{array}$ \\
\hline Number of children $<5$ & $\begin{array}{l}-0.020^{* * *} \\
(2.59)\end{array}$ & $\begin{array}{l}-0.020^{* *} \\
(2.44)\end{array}$ & $\begin{array}{l}-0.017 \\
(1.36)\end{array}$ & $\begin{array}{l}-0.018 \\
(1.45)\end{array}$ \\
\hline Child's birth order & $\begin{array}{l}-0.008^{* *} \\
(2.18)\end{array}$ & $\begin{array}{l}-0.008^{* *} \\
(2.04)\end{array}$ & $\begin{array}{l}-0.014^{* * *} \\
(2.81)\end{array}$ & $\begin{array}{l}-0.014^{* * *} \\
(2.93)\end{array}$ \\
\hline Household wealth & $\begin{array}{l}0.018 \\
(0.95)\end{array}$ & $\begin{array}{l}0.018 \\
(0.93)\end{array}$ & $\begin{array}{l}0.051^{* * *} \\
(4.13)\end{array}$ & $\begin{array}{l}0.051^{* * *} \\
(4.08)\end{array}$ \\
\hline Nondurable PCE & $\begin{array}{l}-0.006 \\
(0.38)\end{array}$ & $\begin{array}{l}-0.006 \\
(0.34)\end{array}$ & $\begin{array}{l}0.029 \\
(1.49)\end{array}$ & $\begin{array}{l}0.029 \\
(1.46)\end{array}$ \\
\hline Health better than peers & $\begin{array}{l}-0.020 \\
(1.36)\end{array}$ & $\begin{array}{l}-0.020 \\
(1.33)\end{array}$ & $\begin{array}{l}0.038^{* *} \\
(2.18)\end{array}$ & $\begin{array}{l}0.036^{* *} \\
(1.94)\end{array}$ \\
\hline Health worse than peers & $\begin{array}{l}-0.082^{* *} \\
(2.02)\end{array}$ & $\begin{array}{l}-0.082^{* *} \\
(2.02)\end{array}$ & $\begin{array}{l}-0.012 \\
(0.35)\end{array}$ & $\begin{array}{l}-0.019 \\
(0.56)\end{array}$ \\
\hline Had serious illness/injury & $\begin{array}{l}-0.028^{*} \\
(1.65)\end{array}$ & $\begin{array}{l}-0.027 \\
(1.54)\end{array}$ & $\begin{array}{l}-0.007 \\
(0.31)\end{array}$ & $\begin{array}{l}-0.008 \\
(0.34)\end{array}$ \\
\hline Father ill & $\begin{array}{l}0.011 \\
(0.69)\end{array}$ & $\begin{array}{l}0.010 \\
(0.66)\end{array}$ & $\begin{array}{l}0.017 \\
(0.51)\end{array}$ & $\begin{array}{l}0.015 \\
(0.47)\end{array}$ \\
\hline Mother ill & -0.016 & -0.015 & 0.003 & 0.006 \\
\hline
\end{tabular}




$\begin{array}{lllll} & (0.81) & (0.79) & (0.08) & (0.16) \\ \text { Household member ill } & -0.001 & -0.001 & 0.019 & 0.019 \\ & (0.07) & (0.03) & (0.77) & (0.77) \\ \text { Constant } & 0.949^{* * *} & 0.948^{* * *} & 0.543^{* * *} & 0.556^{* * *} \\ & (14.07) & (13.56) & (4.61) & (4.63) \\ \text { Community fixed effects } & \text { Yes } & \text { Yes } & \text { Yes } & \text { Yes } \\ \text { Observations } & 971 & 971 & 971 & 971 \\ \text { Community effects } & \text { Yes } & \text { Yes } & \text { Yes } & \text { Yes } \\ \text { Adjusted R } & 0.07 & 0.07 & 0.12 & 0.13\end{array}$

Notes: Dependent variable: School enrollment. Coefficients from a linear probability model are reported. $|z|$ ratios are shown in parentheses and are based on bootstrapped standard errors clustered at the site/community level. ${ }^{* * *}$-shows significance at $1 \%$; ${ }^{* *}$-shows significance at $5 \%$; ${ }^{*}$-shows significance at $10 \%$. 
Table 6: Children's endowment and participation in work: Endowment measured as residual

\begin{tabular}{|c|c|c|c|c|}
\hline \multirow[b]{2}{*}{ Female } & \multicolumn{2}{|c|}{ Age 12} & \multicolumn{2}{|c|}{ Age 15} \\
\hline & $\begin{array}{l}-0.236^{* * *} \\
(5.09)\end{array}$ & $\begin{array}{l}-0.236^{* * *} \\
(5.12)\end{array}$ & $\begin{array}{l}-0.395^{* * *} \\
(7.35)\end{array}$ & $\begin{array}{l}-0.396^{* * *} \\
(7.98)\end{array}$ \\
\hline Residual PPVT & $\begin{array}{l}-0.002^{* * *} \\
(2.61)\end{array}$ & $\begin{array}{l}-0.002^{* *} \\
(2.15)\end{array}$ & $\begin{array}{l}-0.001^{*} \\
(1.74)\end{array}$ & $\begin{array}{l}-0.001 \\
(1.51)\end{array}$ \\
\hline Residual PPVT squared & & $\begin{array}{l}-0.000 \\
(0.86)\end{array}$ & & $\begin{array}{l}0.006 \times 10^{-2 * * *} \\
(2.63)\end{array}$ \\
\hline Female $\times$ Residual PPVT & & $\begin{array}{l}-0.001 \\
(0.51)\end{array}$ & & $\begin{array}{l}0.001 \\
(0.82)\end{array}$ \\
\hline Mother's schooling & $\begin{array}{l}-0.002 \\
(0.62)\end{array}$ & $\begin{array}{l}-0.003 \\
(0.64)\end{array}$ & $\begin{array}{l}-0.008 \\
(1.42)\end{array}$ & $\begin{array}{l}-0.008 \\
(1.36)\end{array}$ \\
\hline Father's schooling & $\begin{array}{l}-0.004 \\
(1.17)\end{array}$ & $\begin{array}{l}-0.004 \\
(1.22)\end{array}$ & $\begin{array}{l}-0.001 \\
(0.18)\end{array}$ & $\begin{array}{l}-0.000 \\
(0.03)\end{array}$ \\
\hline Caregiver's age & $\begin{array}{l}-0.004^{* * *} \\
(2.95)\end{array}$ & $\begin{array}{l}-0.004^{* * *} \\
(3.27)\end{array}$ & $\begin{array}{l}-0.001 \\
(0.28)\end{array}$ & $\begin{array}{l}-0.000 \\
(0.23)\end{array}$ \\
\hline Head's age & $\begin{array}{l}0.005^{* * *} \\
(3.85)\end{array}$ & $\begin{array}{l}0.005^{* * * *} \\
(3.82)\end{array}$ & $\begin{array}{l}0.002 \\
(1.47)\end{array}$ & $\begin{array}{l}0.002 \\
(1.47)\end{array}$ \\
\hline Other caregiver & $\begin{array}{l}0.080^{* * *} \\
(2.64)\end{array}$ & $\begin{array}{l}0.084^{* * *} \\
(2.74)\end{array}$ & $\begin{array}{l}-0.001 \\
(0.04)\end{array}$ & $\begin{array}{l}-0.014 \\
(0.45)\end{array}$ \\
\hline Female head & $\begin{array}{l}-0.034 \\
(1.03)\end{array}$ & $\begin{array}{l}-0.033 \\
(1.02)\end{array}$ & $\begin{array}{l}0.005 \\
(0.20)\end{array}$ & $\begin{array}{l}0.004 \\
(0.17)\end{array}$ \\
\hline Number of adults & $\begin{array}{l}0.011 \\
(1.52)\end{array}$ & $\begin{array}{l}0.011 \\
(1.45)\end{array}$ & $\begin{array}{l}0.006 \\
(0.70)\end{array}$ & $\begin{array}{l}0.006 \\
(0.69)\end{array}$ \\
\hline Number of siblings & $\begin{array}{l}-0.003 \\
(0.22)\end{array}$ & $\begin{array}{l}-0.002 \\
(0.17)\end{array}$ & $\begin{array}{l}-0.002 \\
(0.25)\end{array}$ & $\begin{array}{l}-0.005 \\
(0.53)\end{array}$ \\
\hline Number of sisters & $\begin{array}{l}0.031^{* * *} \\
(2.90)\end{array}$ & $\begin{array}{l}0.031^{* * *} \\
(2.77)\end{array}$ & $\begin{array}{l}0.001 \\
(0.09)\end{array}$ & $\begin{array}{l}0.002 \\
(0.20)\end{array}$ \\
\hline Number of children $<5$ & $\begin{array}{l}-0.009 \\
(0.52)\end{array}$ & $\begin{array}{l}-0.009 \\
(0.52)\end{array}$ & $\begin{array}{l}-0.013 \\
(0.51)\end{array}$ & $\begin{array}{l}-0.011 \\
(0.47)\end{array}$ \\
\hline Child's birth order & $\begin{array}{l}-0.005 \\
(0.81)\end{array}$ & $\begin{array}{l}-0.004 \\
(0.73)\end{array}$ & $\begin{array}{l}-0.004 \\
(0.50)\end{array}$ & $\begin{array}{l}-0.005 \\
(0.60)\end{array}$ \\
\hline Household wealth & $\begin{array}{l}-0.057^{* *} \\
(2.24)\end{array}$ & $\begin{array}{l}-0.058^{* *} \\
(2.23)\end{array}$ & $\begin{array}{l}-0.039^{*} \\
(1.66)\end{array}$ & $\begin{array}{l}-0.038 \\
(1.61)\end{array}$ \\
\hline Nondurable PCE & $\begin{array}{l}0.054^{*} \\
(1.85)\end{array}$ & $\begin{array}{l}0.055^{* *} \\
(1.99)\end{array}$ & $\begin{array}{l}-0.057^{* * *} \\
(2.84)\end{array}$ & $\begin{array}{l}-0.058^{* * *} \\
(2.89)\end{array}$ \\
\hline Health better than peers & $\begin{array}{l}-0.050^{*} \\
(1.76)\end{array}$ & $\begin{array}{l}-0.049^{*} \\
(1.73)\end{array}$ & $\begin{array}{l}-0.078^{* * *} \\
(3.76)\end{array}$ & $\begin{array}{l}-0.075^{* * *} \\
(3.64)\end{array}$ \\
\hline Health worse than peers & $\begin{array}{l}-0.081^{*} \\
(1.62)\end{array}$ & $\begin{array}{l}-0.082^{*} \\
(1.64)\end{array}$ & $\begin{array}{l}-0.011^{* *} \\
(2.12)\end{array}$ & $\begin{array}{l}-0.102^{* *} \\
(1.95)\end{array}$ \\
\hline Had serious illness/injury & $\begin{array}{l}0.028 \\
(0.89)\end{array}$ & $\begin{array}{l}0.030 \\
(0.98)\end{array}$ & $\begin{array}{l}-0.042 \\
(1.39)\end{array}$ & $\begin{array}{l}-0.040 \\
(1.30)\end{array}$ \\
\hline Father ill & $\begin{array}{l}-0.022 \\
(0.54)\end{array}$ & $\begin{array}{l}-0.022 \\
(0.57)\end{array}$ & $\begin{array}{l}0.040 \\
(1.03)\end{array}$ & $\begin{array}{l}0.041 \\
(1.03)\end{array}$ \\
\hline Mother ill & -0.013 & -0.011 & $-0.054^{*}$ & $-0.059 * *$ \\
\hline
\end{tabular}




\begin{tabular}{lllll} 
& $(0.40)$ & $(0.33)$ & $(1.82)$ & $(2.00)$ \\
Household member ill & -0.007 & -0.006 & -0.004 & -0.005 \\
& $(0.16)$ & $(0.14)$ & $(0.15)$ & $(0.17)$ \\
Constant & $0.364^{* * *}$ & $0.364^{* * *}$ & $0.979^{* * *}$ & $0.954^{* * *}$ \\
& $(2.46)$ & $(2.46)$ & $(8.22)$ & $(8.20)$ \\
Community fixed effects & Yes & Yes & Yes & Yes \\
Observations & 970 & 970 & 970 & 970 \\
Adjusted R & 0.40 & 0.40 & 0.35 & 0.36 \\
\hline
\end{tabular}

Notes: Dependent variable: Participation in work. Coefficients from a linear probability model are reported. $|z|$ ratios are shown in parentheses and are based on bootstrapped standard errors clustered at the site/community level. ${ }^{* *}$-shows significance at $1 \%{ }^{* *}$-shows significance at $5 \%$; ${ }^{*}$-shows significance at $10 \%$. 
Table 7: Children's endowment and work hours: Endowment measured as residual

\begin{tabular}{|c|c|c|c|c|}
\hline & \multicolumn{2}{|c|}{ Age 12} & \multicolumn{2}{|c|}{ Age 15} \\
\hline & Tobit $^{\mathrm{a}}$ & Honoré b & Tobit $^{\mathrm{a}}$ & Honoré b \\
\hline \multirow[t]{2}{*}{ Female } & $-0.858^{* * *}$ & $-2.200 * * *$ & $-1.480 * * *$ & $-3.913 * * *$ \\
\hline & $(9.20)$ & $(8.71)$ & $(15.52)$ & $(7.88)$ \\
\hline \multirow[t]{2}{*}{ PPVT } & $-0.009 * * *$ & $-0.021^{* * *}$ & $-0.006^{* * *}$ & $-0.021 * *$ \\
\hline & $(4.04)$ & $(4.56)$ & $(3.11)$ & $(2.43)$ \\
\hline \multirow[t]{2}{*}{ Mother's schooling } & -0.021 & -0.063 & -0.030 & $-0.109 * *$ \\
\hline & $(1.32)$ & $(1.29)$ & $(1.45)$ & $(2.19)$ \\
\hline \multirow[t]{2}{*}{ Father's schooling } & -0.014 & $-0.085^{* *}$ & -0.004 & -0.030 \\
\hline & $(1.14)$ & $(2.05)$ & $(0.24)$ & $(0.53)$ \\
\hline \multirow[t]{2}{*}{ Caregiver's age } & $-0.016 * *$ & -0.025 & -0.005 & -0.007 \\
\hline & $(2.27)$ & $(1.58)$ & $(0.65)$ & $(0.35)$ \\
\hline \multirow[t]{2}{*}{ Head's age } & $0.013^{* *}$ & 0.012 & 0.009 & 0.008 \\
\hline & $(2.17)$ & $(0.75)$ & $(1.21)$ & $(0.71)$ \\
\hline \multirow[t]{2}{*}{ Other caregiver } & $0.332 * *$ & $1.124^{* * *}$ & 0.126 & 0.355 \\
\hline & $(2.01)$ & $(2.50)$ & $(0.94)$ & $(0.76)$ \\
\hline \multirow[t]{2}{*}{ Female head } & -0.125 & -0.400 & 0.053 & 0.347 \\
\hline & $(0.89)$ & $(1.02)$ & $(0.33)$ & $(1.02)$ \\
\hline \multirow[t]{2}{*}{ Number of adults } & $0.062^{* *}$ & 0.032 & 0.036 & 0.063 \\
\hline & $(2.17)$ & $(0.37)$ & $(1.07)$ & $(0.81)$ \\
\hline \multirow[t]{2}{*}{ Number of siblings } & -0.045 & $-0.147 * *$ & 0.010 & -0.031 \\
\hline & $(1.45)$ & $(2.11)$ & $(0.24)$ & $(0.23)$ \\
\hline \multirow[t]{2}{*}{ Number of sisters } & $0.108^{* * *}$ & $0.222^{* * *}$ & -0.030 & -0.124 \\
\hline & $(2.61)$ & $(2.85)$ & $(0.55)$ & $(0.75)$ \\
\hline \multirow[t]{2}{*}{ Number of children $<5$} & 0.008 & -0.014 & -0.013 & -0.095 \\
\hline & $(0.15)$ & $(0.12)$ & $(0.14)$ & $(0.45)$ \\
\hline \multirow[t]{2}{*}{ Child's birth order } & 0.003 & $0.088^{* * *}$ & -0.005 & 0.004 \\
\hline & $(0.17)$ & $(2.80)$ & $(0.20)$ & $(0.04)$ \\
\hline \multirow[t]{2}{*}{ Household wealth } & $-0.160^{* *}$ & -0.156 & $-0.238^{* * *}$ & -0.356 \\
\hline & $(2.28)$ & $(0.42)$ & $(2.96)$ & $(1.32)$ \\
\hline \multirow[t]{2}{*}{ Nondurable PCE } & 0.116 & 0.370 & $-0.270^{* * *}$ & $-0.767^{* *}$ \\
\hline & $(1.55)$ & $(1.09)$ & $(2.73)$ & $(2.18)$ \\
\hline \multirow[t]{2}{*}{ Health better than peers } & $-0.156^{* *}$ & -0.083 & $-0.198^{* *}$ & $-0.561^{*}$ \\
\hline & $(2.28)$ & $(0.42)$ & $(2.08)$ & $(1.80)$ \\
\hline \multirow[t]{2}{*}{ Health worse than peers } & -0.101 & 0.233 & $-0.407^{* * *}$ & -0.467 \\
\hline & $(0.70)$ & $(0.73)$ & $(2.43)$ & $(0.91)$ \\
\hline \multirow[t]{2}{*}{ Had serious illness/injury } & $0.209^{*}$ & 0.340 & -0.140 & -0.385 \\
\hline & $(1.73)$ & $(1.08)$ & $(1.22)$ & $(0.80)$ \\
\hline \multirow[t]{2}{*}{ Father ill } & -0.069 & -0.268 & 0.125 & -0.012 \\
\hline & $(0.68)$ & $(0.96)$ & $(0.82)$ & $(0.03)$ \\
\hline \multirow[t]{2}{*}{ Mother ill } & -0.042 & 0.010 & -0.083 & -0.167 \\
\hline & $(0.34)$ & $(0.03)$ & $(0.83)$ & $(0.49)$ \\
\hline \multirow[t]{2}{*}{ Household member ill } & -0.046 & -0.131 & 0.071 & -0.054 \\
\hline & $(0.43)$ & $(0.66)$ & $(0.62)$ & $(0.12)$ \\
\hline Urban & $-0.937^{* * *}$ & & $-0.443^{* * *}$ & \\
\hline
\end{tabular}


(6.44)

Community fixed effects

Observations

Pseudo R² (Prob. > Chi ${ }^{2}$ )

Notes: Dependent variable: Hours of work.

a - Marginal effects (conditional) from a tobit model are reported. $|z|$ ratios are shown in parentheses and are based on bootstrapped standard errors clustered at the site/community level. The tobit regressions also included regional dummies and a constant.

b - Coefficients from Honoré's (1992) semiparametric censored fixed effects model are reported. $|\mathrm{z}|$ ratios based on bootstrapped standard errors are shown in parentheses.

***-shows significance at $1 \% ;{ }^{* *}$-shows significance at $5 \% ;{ }^{*}$-shows significance at $10 \%$.
$(4.10)$

No Yes

$970 \quad 970$

$0.13 \quad 0.00$ 
Table 8: Children's endowment, school enrollment and work: Household fixed effects estimates using sibling pairs

\begin{tabular}{|c|c|c|c|c|c|c|}
\hline \multirow[b]{2}{*}{ Female } & \multicolumn{2}{|c|}{$\begin{array}{c}\text { School } \\
\text { enrollment }^{\mathrm{a}}\end{array}$} & \multicolumn{2}{|c|}{$\begin{array}{c}\text { Work } \\
\text { status }^{b}\end{array}$} & \multicolumn{2}{|c|}{$\begin{array}{l}\text { Work } \\
\text { hours }^{\mathrm{c}}\end{array}$} \\
\hline & $\begin{array}{l}0.057^{* * *} \\
(2.80)\end{array}$ & $\begin{array}{l}0.053^{* * *} \\
(2.59)\end{array}$ & $\begin{array}{l}-0.430^{* * *} \\
(15.97)\end{array}$ & $\begin{array}{l}-0.425^{* * *} \\
(15.91)\end{array}$ & $\begin{array}{l}-3.936^{* * *} \\
(11.66)\end{array}$ & $\begin{array}{l}-3.909^{* * *} \\
(10.92)\end{array}$ \\
\hline PPVT & $\begin{array}{l}0.046^{* * *} \\
(2.90)\end{array}$ & $\begin{array}{l}0.056^{* * *} \\
(2.78)\end{array}$ & $\begin{array}{l}-0.046^{* *} \\
(2.20)\end{array}$ & $\begin{array}{l}-0.051^{*} \\
(1.91)\end{array}$ & $\begin{array}{l}-0.611^{* * *} \\
(3.29)\end{array}$ & $\begin{array}{l}-0.060 \\
(0.23)\end{array}$ \\
\hline PPVT squared & & $\begin{array}{l}-0.023^{* *} \\
(2.15)\end{array}$ & & $\begin{array}{l}0.039^{* * *} \\
(2.75)\end{array}$ & & $\begin{array}{l}0.437^{* * *} \\
(2.93)\end{array}$ \\
\hline Female $\times$ PPVT & & $\begin{array}{l}-0.067^{* * *} \\
(3.28)\end{array}$ & & $\begin{array}{l}0.084^{* * *} \\
(3.16)\end{array}$ & & $\begin{array}{l}-0.094 \\
(0.28)\end{array}$ \\
\hline Constant & $\begin{array}{l}0.329^{* * *} \\
(2.96)\end{array}$ & $\begin{array}{l}0.347 \\
(3.13)\end{array}$ & $\begin{array}{l}0.687^{* * *} \\
(4.73)\end{array}$ & & & \\
\hline Age dummies & Yes & Yes & Yes & $\begin{array}{l}0.654^{* * *} \\
(4.53)\end{array}$ & Yes & Yes \\
\hline HH fixed effects & Yes & Yes & Yes & Yes & Yes & Yes \\
\hline Observations & 1346 & 1346 & 1343 & 1343 & 1343 & 1343 \\
\hline F stat. $\left(\mathrm{Chi}^{2}\right)$ & 5.78 & 6.14 & 24.09 & 22.16 & 165.04 & 200.23 \\
\hline Prob. > F $\left(\mathrm{Chi}^{2}\right)$ & 0.000 & 0.000 & 0.000 & 0.000 & 0.000 & 0.000 \\
\hline
\end{tabular}

Notes: ${ }^{\mathrm{a}, \mathrm{b}}$ - Coefficients from a linear probability model are reported.

c - Coefficients from Honoré's (1992) semiparametric censored fixed effects model are reported.

- $|\mathrm{t}|$ ratios are shown in parentheses. ${ }^{* *}$-shows significance at $1 \%$; ${ }^{* *}$-shows significance at $5 \%$; ${ }^{*}$-shows significance at $10 \%$. 


\section{APPENDIX}

Table A1: Predicting children's educational endowment

\begin{tabular}{ll}
\hline & PPVT \\
& \\
\hline Female & $-5.986^{* * *}$ \\
& $(3.69)$ \\
Age & $35.607^{* *}$ \\
& $(2.07)$ \\
Age squared & -0.730 \\
& $(1.15)$ \\
Mother's schooling & 0.060 \\
& $(0.23)$ \\
Father's schooling & $0.568^{* * *}$ \\
& $(2.69)$ \\
Female $\times$ Mother's schooling & $0.972^{* * *}$ \\
& $(2.47)$ \\
Female $\times$ Father's schooling & $-0.583^{*}$ \\
& $(1.81)$ \\
Completed grade & $12.033^{* * *}$ \\
& $(21.54)$ \\
Constant & $-284.310^{* * *}$ \\
& $(2.46)$ \\
Observations & 1916 \\
Adjusted R ${ }^{2}$ & 0.69 \\
\hline
\end{tabular}

Notes: Dependent variable: Raw PPVT score. Coefficients from a pooled OLS model (Ages 12 and 15) are reported. $|z|$ ratios are shown in parentheses and are based on bootstrapped standard errors.

a - predicted from the regression in Table A2 below. 
Table A2: Predicting children's completed grade

\begin{tabular}{|c|c|}
\hline & Grade \\
\hline Female & $\begin{array}{l}0.210^{* *} \\
(2.23)\end{array}$ \\
\hline Age & $\begin{array}{l}0.828 \\
(0.84)\end{array}$ \\
\hline Age squared & $\begin{array}{l}-0.022 \\
(0.61)\end{array}$ \\
\hline Mother's schooling & $\begin{array}{l}0.030 \\
(1.62)\end{array}$ \\
\hline Father's schooling & $\begin{array}{l}0.036^{* *} \\
(2.38)\end{array}$ \\
\hline Female $\times$ Mother's schooling & $\begin{array}{l}0.012 \\
(0.51)\end{array}$ \\
\hline Female $\times$ Father's schooling & $\begin{array}{l}-0.006 \\
(0.28)\end{array}$ \\
\hline Caregiver's age & $\begin{array}{l}0.010^{* *} \\
(2.20)\end{array}$ \\
\hline Other caregiver & $\begin{array}{l}-0.377^{* * *} \\
(2.94)\end{array}$ \\
\hline Number of siblings & $\begin{array}{l}0.039 \\
(1.45)\end{array}$ \\
\hline Number of children $<5$ & $\begin{array}{l}-0.149^{* *} \\
(2.32)\end{array}$ \\
\hline Child's birth order & $\begin{array}{l}-0.017 \\
(0.90)\end{array}$ \\
\hline Household wealth & $\begin{array}{l}0.193^{* * *} \\
(2.57)\end{array}$ \\
\hline Nondurable PCE & $\begin{array}{l}0.381^{* * *} \\
(4.45)\end{array}$ \\
\hline Health better than peers & $\begin{array}{l}0.094 \\
(1.16)\end{array}$ \\
\hline Health worse than peers & $\begin{array}{l}-0.123 \\
(0.99)\end{array}$ \\
\hline Had serious illness/injury & $\begin{array}{l}-0.227^{* *} \\
(2.35)\end{array}$ \\
\hline Father ill & $\begin{array}{l}0.016 \\
(0.15)\end{array}$ \\
\hline Mother ill & $\begin{array}{l}-0.008 \\
(0.08)\end{array}$ \\
\hline Household member ill & $\begin{array}{l}-0.024 \\
(0.25)\end{array}$ \\
\hline Constant & $\begin{array}{l}-5.236 \\
(0.79)\end{array}$ \\
\hline Community $\times$ Round dummies & Yes \\
\hline
\end{tabular}




\begin{tabular}{ll} 
Observations & 1942 \\
$\mathrm{R}^{2}$ & 0.53 \\
\hline
\end{tabular}

Notes: Dependent variable: Completed grade in school. Coefficients from a pooled OLS model (Ages 12 and 15) are reported. It | ratios based on robust standard errors are shown in parentheses. 